\title{
Modelling the effect of soil moisture and organic matter degradation on biogenic NO emissions from soils in Sahel rangeland (Mali)
}

\author{
C. Delon ${ }^{1}$, E. Mougin ${ }^{2}$, D. Serça ${ }^{1}$, M. Grippa ${ }^{2}$, P. Hiernaux ${ }^{2}$, M. Diawara ${ }^{2}$, C. Galy-Lacaux ${ }^{1}$, and L. Kergoat ${ }^{2}$ \\ ${ }^{1}$ Laboratoire d'Aérologie, Université de Toulouse and CNRS, Toulouse, France \\ ${ }^{2}$ Geosciences Environnement Toulouse, Université de Toulouse, CNRS and IRD, Toulouse, France \\ Correspondence to: C. Delon (claire.delon@aero.obs-mip.fr)
}

Received: 12 December 2014 - Published in Biogeosciences Discuss.: 16 January 2015

Revised: 5 May 2015 - Accepted: 9 May 2015 - Published: 3 June 2015

\begin{abstract}
This work is an attempt to provide seasonal variation of biogenic NO emission fluxes in a Sahelian rangeland in Mali (Agoufou, $15.34^{\circ} \mathrm{N}, 1.48^{\circ} \mathrm{W}$ ) for years 2004 , 2005, 2006, 2007 and 2008. Indeed, NO is one of the most important precursors for tropospheric ozone, and previous studies have shown that arid areas potentially display significant NO emissions (due to both biotic and abiotic processes). Previous campaigns in the Sahel suggest that the contribution of this region in emitting NO is no longer considered as negligible. However, very few data are available in this region, therefore this study focuses on model development. The link between NO production in the soil and NO release to the atmosphere is investigated in this modelling study, by taking into account vegetation litter production and degradation, microbial processes in the soil, emission fluxes, and environmental variables influencing these processes, using a coupled vegetation-litter decompositionemission model. This model includes the Sahelian Transpiration Evaporation and Productivity (STEP) model for the simulation of herbaceous, tree leaf and faecal masses, the GENDEC model (GENeral DEComposition) for the simulation of the buried litter decomposition and microbial dynamics, and the NO emission model (NOFlux) for the simulation of the NO release to the atmosphere. Physical parameters (soil moisture and temperature, wind speed, sand percentage) which affect substrate diffusion and oxygen supply in the soil and influence the microbial activity, and biogeochemical parameters ( $\mathrm{pH}$ and fertilization rate related to $\mathrm{N}$ content) are necessary to simulate the NO flux. The reliability of the simulated parameters is checked, in order to assess the robustness of the simulated NO flux. Simulated yearly average of NO flux ranges from 2.09 to $3.04 \mathrm{ng}(\mathrm{N}) \mathrm{m}^{-2} \mathrm{~s}^{-1}$ (0.66 to
\end{abstract}

$\left.0.96 \mathrm{~kg}(\mathrm{~N}) \mathrm{ha}^{-1} \mathrm{yr}^{-1}\right)$, and wet season average ranges from 3.36 to $5.48 \mathrm{ng}(\mathrm{N}) \mathrm{m}^{-2} \mathrm{~s}^{-1}$ (1.06 to $1.73 \mathrm{~kg}(\mathrm{~N}) \mathrm{ha}^{-1} \mathrm{yr}^{-1}$ ). These results are of the same order as previous measurements made in several sites where the vegetation and the soil are comparable to the ones in Agoufou. This coupled vegetationlitter decomposition-emission model could be generalized at the scale of the Sahel region, and provide information where few data are available.

\section{Introduction}

In the continental biosphere, most of the $\mathrm{N}$ cycle is accomplished through internal processes such as mineralization/assimilation, because $\mathrm{N}$ is mostly assimilated in the biosphere from its mineral form (nitrates $\mathrm{NO}_{3}^{-}$, ammonium $\mathrm{NH}_{4}^{+}$). In natural soils, these compounds come from biological nitrogen fixation (BNF, Vitousek et al., 2013), from atmospheric dry and wet deposition (Laouali et al., 2012; Galy-Lacaux et al., 2009) and from the mineralization of organic matter through the bacterial and fungal decomposition of dead matter. $\mathrm{N}$ cycle in the soil is dominated by microbial transformations. Bacterial processes involve important reactive gaseous components, e.g. NO formation through nitrification and denitrification (Delmas et al., 1995; Schreiber et al., 2012; Medinets et al., 2015). A significant fraction of these compounds can be released to the atmosphere. NO is one of the most important precursors for tropospheric ozone, and participates in the formation of nitric acid, participating in $\mathrm{N}$ deposition. $\mathrm{NO}_{x}\left(\mathrm{NO}_{x}=\mathrm{NO}+\mathrm{NO}_{2}\right)$ are also involved in the abundance of the hydroxyl radical $(\mathrm{OH})$ which deter- 
mines the lifetime of some pollutants and greenhouse gases (Fowler et al., 2009).

Atmospheric $\mathrm{NO}_{x}$ is coupled to the Earth's nitrogen cycle through complex interactions involving soil microbial activity, soil $\mathrm{N}$ content and $\mathrm{N}$ inputs to the soil, either from anthropogenic or atmospheric origin (Hudman et al., 2012; Parton et al., 2001). The processes of NO production and consumption in the soil have been studied through modelling, laboratory or field studies by several authors (Butterbach-Bahl et al., 2004a; Schindblacher et al., 2004; Li et al., 2000) for different types of soils and climates (Butterbach-Bahl et al., 2009 and Kesik et al., 2005 for European soils, Feig et al., 2008 and Meixner et al., 1997 for tropical soils as examples). The release of $\mathrm{NO}$ (NO emission) to the atmosphere is the result of production and consumption processes in the soil. In many previous studies it was observed that the NO release equals the NO production minus the NO consumption. Several biotic and abiotic processes in soils and plants are responsible for the production and consumption of $\mathrm{NO}$ (Galbally and Johansson, 1989; Conrad, 1996; Medinets et al., 2015; Pilegaard, 2013). Microbial nitrification and denitrification constitute the principal processes (Ludwig et al., 2001). According to McCalley and Sparks (2008) and references therein, fluxes are regulated by factors that include the concentration of inorganic $\mathrm{N}\left(\mathrm{NO}_{3}^{-}\right.$and $\left.\mathrm{NH}_{4}^{+}\right)$, soil moisture, temperature, accessibility of labile $\mathrm{C}$, and physical soil properties. Most of the trace gas production and consumption processes in soil (trace gases such as $\mathrm{NO}, \mathrm{N}_{2} \mathrm{O}, \mathrm{CH}_{4}, \mathrm{CO}$ ) are probably due to microorganisms (Pilegaard, 2013; Conrad, 1996; Fowler et al., 2009). Oxidation of NO to nitrate has been found to be the dominant NO consumption mechanism in some soils (Conrad, 1996 and references therein). Release rates of NO can be much lower than the NO production rates, since NO consumption is of similar magnitude to NO production. NO shows both high and variable production and consumption rates in soil and consequently highly dynamic compensation points (Conrad, 1996). The concept of the compensation concentration is based on the observation that production and consumption of a trace gas occur simultaneously in a soil and that the consumption rate is a function of the trace gas concentration, whereas the production rate is not (Conrad, 1994). According to Ludwig et al. (2001), the net exchange of NO between ecosystems and the atmosphere is globally dominated by biogenic emissions of NO from soils. Only at exceptionally high ambient NO concentration might direct deposition to plants constitute a significant removal mechanism for atmospheric $\mathrm{NO}$ (Ludwig et al., 2001). After $\mathrm{NO}$ is oxidized into $\mathrm{NO}_{2}$, the $\mathrm{NO}_{2}$ can be deposited on the vegetation, decreasing the net emission of NO above canopy to the atmosphere. Above-canopy emissions are calculated by introducing the canopy reduction factor (CRF) concept, based on the leaf area index (LAI), and considering the canopy as an absorber of $\mathrm{NO}_{2}$ (Yienger and Levy, 1995; Butterbach-Bahl et al., 2004b).
NO release in arid and semi-arid soils are mainly governed by pulse events, produced when first precipitations shower long-dried soils at the beginning of the rainy season. Several studies have shown that pulse emissions of NO contribute strongly to the total emission (Yan et al., 2005; Hudman et al., 2010; Jaeglé et al., 2004; Kim et al., 2012), specifically in semi-arid regions. In those regions, mineral and organic substrates tend to accumulate at the soil surface and in the soil during the long dry season, when there is little nutrient demand, leading to an excess of mineralization during the early phases of the wet cycle (Schwinning et al., 2004).

At the global scale, $\mathrm{NO}$ emissions from soils have been estimated to be approximately $21 \mathrm{Tg}(\mathrm{N}) \mathrm{yr}^{-1}$ (Davidson and Kingerlee, 1997) at the ground level (below canopy), a portion of the $\mathrm{NO}_{2}$ being deposited within the canopy. Abovecanopy emissions were estimated to be $5.45 \mathrm{Tg}(\mathrm{N}) \mathrm{yr}^{-1}$ by one of the first global modelling study on the subject (Yienger and Levy, 1995), and more recently up to $8.6 \mathrm{Tg}(\mathrm{N}) \mathrm{yr}^{-1}$ (Steinkamp and Lawrence, 2011) and $10.7 \mathrm{Tg}(\mathrm{N}) \mathrm{yr}^{-1}$ (Hudman et al., 2012). At the scale of the Sahelian region, Delon et al. (2010) have calculated a $0.5 \pm 0.1 \mathrm{Tg}(\mathrm{N}) \mathrm{yr}^{-1}$ above-canopy $\mathrm{NO}_{x}$ emission, representing 5 to $10 \%$ of the global budget according to Hudman et al. (2012) or Yienger and Levy (1995). Hudman et al. (2012) have shown that the largest pulsed enhancements in their model are predicted over this region during the monsoon onset (April to June), comprising 15 to $65 \%$ of the simulated $\mathrm{NO}_{2}$ column and increasing variability by a factor of 5 . As a consequence, the contribution of the Sahel in emitting NO is no longer considered as negligible. Though they are of high interest for the specific mechanisms taking place there, and for their relatively high contribution to the global $\mathrm{N}$ cycle, semi-arid regions remain poorly investigated due to the remoteness of the sites and the complexity of running long-term measurements in difficult conditions. Modelling is therefore a precious help to describe the environmental conditions that favour or not NO emissions. However, in the same time, laboratory and field measurements are necessary to better understand production and consumption processes in the soil leading to the release of NO, and to improve modelling approaches.

In this study, we propose a modelling approach of NO emissions from soils at the yearly and seasonal scale. The goal is to identify production and consumption processes, linked to NO release, through organic matter decomposition and microbial dynamics in the soil, in semi-arid ecosystems. A coupled vegetation-litter decomposition-emission modelling approach is used, which links three existing models specifically developed for semi-arid regions, simulating respectively the growth and degradation of the vegetation (STEP, Mougin et al., 1995), the decomposition of the organic matter and microbial processes in the soil (GENDEC, Moorhead and Reynolds, 1991), and the release of NO (NOFlux, Delon et al., 2007) associated with environmental variables. Modelling results are compared to data collected in 
the northern Mali site of Agoufou for the years 2004 to 2008. This modelling tool has been developed for semi-arid regions where specific processes such as pulses of emission need to be taken into account. Indeed, pulses are usually underestimated by global-scale modelling, and the specificity of a model developed for semi-arid regions helps to provide magnitudes of NO fluxes. In our study, these emissions are related to their biogeochemical origin, to the quantity of biomass, to the quantity of livestock which drives the quantity of organic matter and the $\mathrm{N}$ pool and $\mathrm{N}$ turnover in the soil. Furthermore, the Sahel region is a large region grazed by domestic cattle, and the role of animals in biomass management, as it is included in our modelling approach, is seldom highlighted in regional or global models. This study presents a more detailed emission model than those based on the Yienger and Levy (1995) approach only, and gives an insight in N production processes in the soil at the origin of the emission.

First, the Agoufou site is presented, as well as the different measurements used for model comparison. Then, the three models, STEP, GENDEC and NOFlux, are introduced. Finally, modelling results are discussed and compared to field measurements, and limitations and uncertainties are assessed.

\section{Data source: Agoufou site}

The Agoufou study site (Mali, $15.34^{\circ} \mathrm{N}, 1.48^{\circ} \mathrm{W}$ ) is part of the African Monsoon Multi-disciplinary Analysis (AMMA) - Couplage de l'Atmosphere Tropicale et du Cycle Hydrologique (CATCH) site observatory located in the northern Mali Gourma region. This region stretches from the loop of the Niger River southward down to the border region with Burkina Faso (Mougin et al., 2009). Located towards the northern limit of the area reached by the West African Monsoon, the region experiences a single rainy season with most precipitation falling between late June and mid-September. The rainy season is followed by a long dry season of approximately 8 months. At the Agoufou site, the soil is sandy, with $91.2 \%$ of sand, $3.1 \%$ of silt and $4.6 \%$ of clay in the first $5 \mathrm{~cm}$. The surface $\mathrm{pH}$ is 6.7 . The hydrologic system is endorheic operating at short distance from dune slopes to interdune depressions within small adjacent catchments. The vegetation at Agoufou is an open woody savanna, typical of midSahel sandy soil vegetation with a herbaceous layer almost exclusively composed of annual species, and scattered trees and shrubs with a $3.1 \%$ crown cover (Hiernaux et al., 2009). The area is used as livestock grazing under communal access. Because of the proximity of the Agoufou permanent pond, the grazing pressure is high during the dry season. Agoufou can be considered as representative of Sahelian dry savannas. A comprehensive description of the site can be found in Mougin et al. (2009).

\subsection{Meteorological and vegetation data}

At the Agoufou site, woody and herbaceous plant density and species composition are organized in facies following finer topography and soils nuances or differences in land use practices and histories (Hiernaux et al., 2009). The herbaceous layer has been monitored using a two-level stratified random sampling design, as described in Hiernaux et al. (2009). Total and green vegetation cover (visual and digital photograph estimates in \%, Mougin et al., 2014), standing and litter mass (destructive measure, with harvest, air drying and weighing) and species composition (list with visual estimates of contribution to bulk) are assessed in $1 \times 1 \mathrm{~m}$ plots randomly sampled in each of the vegetated strata along the transect. Aboveground green and dry masses and surface litter mass have been sampled during several years, but only the years 2004 , 2005, 2006, 2007 and 2008 are used in this study to evaluate the performance of the model. Indeed, these years represent contrasted meteorological conditions, with low rainfall years (2004 and 2008) and years with normal rainfall for the region (2005, 2006, 2007). Furthermore, vegetation data are more numerous during these years, when the AMMA experiment took place in West Africa.

A meteorological station was installed from 2002 to 2010, giving data on rainfall, wind speed, relative humidity, air temperature and global radiation. These data were quality checked and gap filled for the years 2004 to 2008 only. Data on soil moisture at different levels and different places (top, middle and bottom locations of dune slope), and soil temperatures at different levels are also available, except for year 2004. A detailed description of the soil moisture network and methodology and of the meteorological station is given in De Rosnay et al. (2009) and Mougin et al. (2009). Meteorological and vegetation data are available in the AMMA database: http://bd.amma-catch.org/ amma-catch2/main.jsf (Redelsperger et al., 2006). Other data are progressively integrated in this database.

\subsection{Calculation of NO flux}

NO fluxes were measured at Agoufou during summers 2004 and 2005, from closed dynamic chambers (flowed-through non-steady-state), defined in Pihlatie et al. (2013). A comprehensive description of the chamber device and calculation flux theory is available in Pape et al. (2009). Stainless steel opaque chambers of $800 \mathrm{~cm}^{2}$ area $(40 \times 20)$ and $18 \mathrm{~cm}$ height were used. A stainless steel frame is inserted into the ground before the measurement which starts when adjusting the chamber on the frame, sealing being assured by a slot filled with water. The air inlet is on one side of the chamber, and the air outlet on the other side is connected to the analyser with $2 \mathrm{~m}$ of Teflon tubing, so that the chamber is swept with an air flow only due to the pump of the instrument. The inflow is not ozone free. Therefore, due to chemical reactions inside the chamber, the fluxes are underestimated. This 
underestimation is calculated (see below) and is small, due to low ozone mixing ratios. The residence time of the air inside the chamber is approximately $10 \mathrm{~min}$. No significant change in air temperature in the chamber has to be noticed during this lapse time. Pressure is assumed to be constant throughout the flux measurement and equal to ambient pressure. A small vent of $4 \mathrm{~mm}$ in diameter provided the pressure equilibrium between the inside and outside of the chamber. As the chamber is ventilated (a circulation of air is always assured by the small vent and the pumping), the system is assumed to be dynamic. Stainless steel is known to be quasi-inert to NO, as is Teflon for tubing, ensuring that NO does not react with the walls of the chamber (Laville et al., 2011). This method has been widely used in the field, as reported for example in Davidson (1991), Serça et al. (1994, 1998), Jambert et al. (1997), Scholes et al. (1997) and Laville et al. (2011).

Several different places at the site of Agoufou were sampled. In June-July 2004, 180 fluxes were sampled. The chambers were placed on the soil, 90 with short vegetation inside, 90 over bare soil. In August 2005, 70 fluxes were sampled, mostly over vegetation, the whole site being covered by vegetation in the core of the wet season. Fluxes were sampled every day between 30 June and 12 July 2004 and between 11 and 13 August 2005, in the morning and in the afternoon. Average values were calculated and are reported in Table 3, with their standard deviations.

Following Davidson (1991) and Serça et al. (1994), the net flux is calculated from the slope of the increase of mixing ratio in ppb within the chamber, assuming that this increase is linear during several minutes (no chemical or deposition loss during that period), and that the air flow is constant. One should note that, as long as the air flow rate is constant, it does not need to be taken into account for the flux calculation (see below). Considering that the mass of $\mathrm{NO}$ within the chamber at time $t+\mathrm{d} t$ is equal to the mass of NO present at time $t$, plus the mass of $\mathrm{NO}$ entering the chamber in the $\mathrm{d} t$ interval (soil flux), minus the mass of NO leaving the chamber in that same $\mathrm{d} t$ interval, if the air flow is constant, only the soil flux has to be taken into account in this mass balance:

$F=\left(\frac{\mathrm{d} C[\mathrm{NO}]}{\mathrm{d} t}\right)\left(\frac{\mathrm{VMN}}{\mathrm{SRT}}\right)$,

where $\frac{\mathrm{d} C[\mathrm{NO}]}{\mathrm{d} t}$ is the initial rate of increase in NO mixing ratio calculated by linear regression $\left(\mathrm{ppb} \mathrm{s}^{-1}\right), \mathrm{MN}$ is the nitrogen molecular weight $\left(\mathrm{g} \mathrm{mol}^{-1}\right), S=800 \mathrm{~cm}^{2}$ is the surface of the chamber, $V=18 \mathrm{~L}$ is the volume of the chamber, $R=$ $0.082 \mathrm{~cm}^{3} \mathrm{~atm}$ mole ${ }^{-1} \mathrm{~K}^{-1}$ is the gas constant, $T(\mathrm{~K})$ is the air temperature in the chamber, and $F$ is the resulting flux in $\mathrm{ng}(\mathrm{N}) \mathrm{m}^{-2} \mathrm{~s}^{-1}$ (Serça et al., 1994).

NO mixing ratio in the chamber was measured using a ThermoEnvironment 42 CTL analyser. This analyser detects $\mathrm{NO}$ by chemiluminescence with $\mathrm{O}_{3}$. Detection limit and sensitivity is around $0.05 \mathrm{ppbv}$, as indicated in the guide, but Laville et al. (2011) found a sensitivity threshold of $0.1 \mathrm{ppbv}$ for the same analyser. Flow rate in the analyser and the chamber is about $0.8 \mathrm{Lmin}^{-1}$. Multipoint calibration was checked before and after each field experiment with a dynamical calibration system. Considering a sensitivity threshold of $0.15 \mathrm{ppbv}$, the minimum flux detected by this device would be $0.25 \mathrm{ng}(\mathrm{N}) \mathrm{m}^{-2} \mathrm{~s}^{-1}$.

The magnitude of ozone mixing ratios is around $20 \mathrm{ppb}$ in July, $\mathrm{NO}_{2}$ mixing ratios around $2.5 \mathrm{ppb}$ (Adon et al., 2010), and $\mathrm{NO}_{2}$ deposition velocity was estimated to be $0.13 \mathrm{~cm} \mathrm{~s}^{-1}$ (Adon et al., 2013; Delon et al., 2010) at the Agoufou site. NO ambient mixing ratios (measured at $20 \mathrm{~cm}$ ) during the 2004 field campaign were $0.60 \pm 0.57 \mathrm{ppb}$ (information not available for the 2005 field campaign). The NO flux is underestimated if neither deposition nor conversion to $\mathrm{NO}_{2}$ through reaction with $\mathrm{O}_{3}$ is taken into account, but the underestimation should be limited considering the low ozone mixing ratios, low $\mathrm{NO}_{2}$ deposition velocities, and no direct radiative radiation in the opaque chamber. Pape et al. (2009) estimate that even for cases with a large absolute chemistry effect (meaning NO fluxes from soils up to $4 \mathrm{ng}(\mathrm{N}) \mathrm{m}^{-2} \mathrm{~s}^{-1}$, with $\mathrm{NO}$ mixing ratios above $5 \mathrm{ppb}$ and ozone mixing ratios between 15 and $20 \mathrm{ppb}$ ), the underestimation due to chemical effects is less than $50 \%$. As a comparison, Laville et al. (2011) finds a maximum underestimation of $25 \%$.

Laville et al. (2011) show that artefacts can be introduced when NO mixing ratios are high (up to $60 \mathrm{ppb}$ ). In our case, NO mixing ratios are much lower than the values indicated by these authors.

Unfortunately, it is not possible to precisely recalculate the underestimation of $\mathrm{NO}$ flux in our study since $\mathrm{NO}_{2}$ mixing ratios measured by the $42^{\circ} \mathrm{C}$ are no longer available. However, following Laville et al. (2011) and Pape et al. (2009), we have calculated the underestimation with the mean climatological ozone mixing ratio found in Adon et al. (2010), which is $20 \mathrm{ppb}$ in July, with $k=$ $5.3210^{-4} \mathrm{ppb}^{-1} \mathrm{~s}^{-1}$ (reaction rate constant at $1013 \mathrm{hPa}$ and $313 \mathrm{~K}$, estimated pressure and temperature in the chamber), and with the mean NO mixing ratio $0.6 \mathrm{ppb}$ obtained with the field measurements in 2004. The mean underestimation $\left(k\right.$. [NO].[O3] $\left.=5.32 \times 10^{-4} \times 20 \times 0.6=0.0064 \mathrm{ppbs}^{-1}\right)$ is $7.6 \%$ of the mean slope $\left(0.0847 \mathrm{ppbs}^{-1}\right.$, obtained from Eq. 1). The mean underestimation is therefore estimated at $7.6 \%$.

During summer 2004 (from 30 June to 12 July), NO daily fluxes ranged from 2.47 to $11.35 \mathrm{ng}(\mathrm{N}) \mathrm{m}^{-2} \mathrm{~s}^{-1}$ (mean $=6.69 \pm 2.44 \mathrm{ng}(\mathrm{N}) \mathrm{m}^{-2} \mathrm{~s}^{-1}$, Delon et al., 2007). During summer 2005 (from 11 to 13 August), NO fluxes ranged from 1.81 to $3.20 \mathrm{ng}(\mathrm{N}) \mathrm{m}^{-2} \mathrm{~s}^{-1}$ (mean $=2.28 \pm 0.79 \mathrm{ng}(\mathrm{N}) \mathrm{m}^{-2} \mathrm{~s}^{-1}$, unpublished data). In the following simulations, NO fluxes were not measured at Agoufou during the years 2006 to 2008. However, since NO flux data are scarce, these field measurements from 2004 and 2005 will be helpful to give an order of magnitude of NO emission at the beginning and during the wet season. 


\section{Model description}

\subsection{Modelling approach}

Biogeochemically based model of instantaneous trace gas production can be parametrized for individual sites, describing local nitrification and denitrification processes responsible for emission, but more generalized models are needed for the calculation of temporally or regionally integrated models (Potter et al., 1996). In that purpose, a new approach for the calculation of biogenic NO emissions from soils has been developed by Delon et al. (2007), in order to use general environmental parameters easily available as inputs. This approach was used at the regional scale to simulate pulse events in the Sahel (Delon et al., 2008) and at the yearly scale at several Sahelian sites (Delon et al., 2010; Laouali et al., 2012). This approach has been partly inspired by the hole-in-thepipe (HIP) concept, developed by Firestone and Davidson (1989), presenting the environmental parameters which control the variation of trace- $\mathrm{N}$-gases by nitrification and denitrification with different levels of regulation, from proximal (e.g. mineralization, immobilization, respiration, plant uptake) to distal (e.g. pH, soil porosity, soil type,...). Using two functions based on soil $\mathrm{N}$ availability and soil water content, the HIP model characterizes a large fraction of the observed variation of NO emissions from soils (Davidson et al., 2000).

The NO emission model will be described in the following sections. In its previous version (Delon et al., 2010), the $\mathrm{N}$ availability in the soil was driven by the $\mathrm{N}$ input at the surface (organic and livestock fertilization) and considered constant in time (a similar amount of $\mathrm{N}$ was injected each month). In the new version, the $\mathrm{N}$ in the soil is calculated from buried litter (vegetation and faeces) decomposition and varies in time, thanks to the coupling with the other models which provide vegetation and organic matter in a dynamic way. The $\mathrm{N}$ input used to calculate the NO flux is therefore more realistic than in the previous version where it was prescribed without any link with vegetation growth and decay. The link between vegetation, litter decomposition, microbial dynamics in the soil and $\mathrm{NO}$ emission is explained in the following sections.

The on-line coupled models are presented here and used at the daily scale: the herbaceous and tree leaf masses are simulated using the Sahelian Transpiration Evaporation and Productivity (STEP) model, the buried litter decomposition and microbial dynamics is simulated in GENDEC, and the NO release to the atmosphere is simulated with the NOFlux model.

A schematic view of the model imbrications is given in Fig. 1. Inputs for each model are detailed in Table 1.

\subsection{STEP}

STEP is an ecosystem process model for Sahelian herbaceous vegetation. In its current version, tree phenology (leaf mass set-up and fall) is also described by considering six phenological types which proportions must be known. This model is defined to be used at local or regional scale in order to simulate the temporal variation of the main variables and processes associated with vegetation functioning in Sahelian savannas. In this study, the model will be used at the local scale. In previous studies, STEP has been coupled to radiative transfer models in the optical (Lo Seen et al., 1995) and active/passive microwave domain (Frison et al., 1998, 2000), allowing an indirect comparison of satellite observations and modelling results of the vegetation growth (e.g. Jarlan et al., 2002). The performance of the STEP process model in predicting herbage mass variation over time and herbage yield along a north-south bio-climatic gradient within the Sahel was tested along a 15-year period, and gave high correlation coefficients between model and measurements when the model was calibrated for each site (Tracol et al., 2006). Modifications brought to the first version of the model have been given in Jarlan et al. (2008). The regional-scale use of the model is illustrated in Jarlan et al. (2003) and Pierre et al. (2012).

STEP is driven by daily standard meteorological data obtained from site measurements in Agoufou (precipitations, global radiation, air temperature, relative humidity and wind speed), prepared for the years 2004 to 2008. Site-specific parameters like sand and clay percentage, $\mathrm{pH}, \mathrm{C} 3 / \mathrm{C} 4$ percentage, initial green biomass, initial dry biomass and initial litter, number of soil layers, initial water content in each layer, livestock composition (between six different categories: cattle, sheep, goats, donkeys, horses, camels) and livestock total load are given as input parameters (see Table 1). The seasonal dynamics of the herbaceous layer, a major component of the Sahelian vegetation, is represented. The processes simulated are: water fluxes in the soil, evaporation from bare soil, transpiration of the vegetation, photosynthesis, respiration, senescence, litter production, and litter decomposition at the soil surface. Moreover, structural parameters such as vegetation cover fraction fCover, LAI (leaf area index) and canopy height are also simulated. A new development has been included in the model for the present study: soil temperatures are simulated from air temperature according to Parton (1984), discussed below. Parton et al. (1984) report a simplified soil temperature model in a short grass steppe. This model requires daily max and min air temperature, global radiation (provided by forcing data), plant biomass (provided by the model), initial soil temperature, and soil thermal diffusivity. Thermal diffusivity $\left(\mathrm{cm}^{2} \mathrm{~s}^{-1}\right)$ is the ratio between thermal conductivity $\left(\mathrm{W} \mathrm{m}^{-2} \mathrm{~K}^{-1}\right)$ and volumetric heat capacity $\left(1500000 \mathrm{~J} \mathrm{~m}^{-3} \mathrm{~K}^{-1}\right)$. Thermal conductivity for each layer $i$ of the soil is

$\operatorname{Cond}(i)=-9.77+12.19 \cdot\left(\right.$ soil moisture $\left.(i)^{0.0528}\right)$.

Total aboveground herbaceous mass is divided into three components: aboveground green mass, standing dead (or dry) biomass, and litter biomass. Green biomass variations 
Table 1. Inputs for the models used.

\begin{tabular}{|c|c|c|c|}
\hline STEP & Inputs & Unit & Value \\
\hline \multirow[t]{3}{*}{ Initial parameters } & Conversion efficiency & $\mathrm{g}(\mathrm{d} . \mathrm{m}.) \mathrm{MJ}^{-1}$ & 4 \\
\hline & Initial green biomass & $\mathrm{g}($ d.m. $) \mathrm{m}^{-2}$ & 0.8 \\
\hline & Initial specific leaf area & $\mathrm{cm}^{2} \mathrm{~g}^{-1}$ & 180 \\
\hline \multirow[t]{5}{*}{ Meteorology } & Precipitations & $\mathrm{mm}$ & Daily variation \\
\hline & Global radiation & $\mathrm{MJ} \mathrm{m}^{-2}$ & Daily variation \\
\hline & Min and max air temperature & ${ }^{\circ} \mathrm{C}$ & Daily variation \\
\hline & Relative humidity & $\%$ & Daily variation \\
\hline & Wind speed & $\mathrm{ms}^{-1}$ & Daily variation \\
\hline \multirow{5}{*}{ Soil } & Thicknesses (4 layers) & $\mathrm{cm}$ & $2 ; 28 ; 70 ; 200$ \\
\hline & Initial water stock (4) & $\mathrm{mm}$ & $0.1 ; 1.5 ; 7.3 ; 38$ \\
\hline & Clay content (4) & & $4.5 ; 5.5 ; 5.2 ; 5.5$ \\
\hline & Sand content (4) & & $91.2 ; 91.3 ; 91 ; 92.3$ \\
\hline & $\mathrm{pH}(4)$ & & $6.7 ; 6.7 ; 6.7 ; 6.7$ \\
\hline \multirow[t]{5}{*}{ Annual vegetation } & Initial dry biomass and litter & $\mathrm{g}(\mathrm{d} . \mathrm{m}.) \mathrm{m}^{-2}$ & $10 ; 30$ \\
\hline & Root fraction (3) & & $0.75 ; 0.2 ; 0.05$ \\
\hline & $\%$ dicotyledon & $\%$ & 29.5 \\
\hline & $\% \mathrm{C} 3$ & $\%$ & 29.3 \\
\hline & $\begin{array}{l}\text { Max tree foliage mass } \\
\text { (year before and current year) }\end{array}$ & $\mathrm{kgha}^{-1}$ & $600 ; 400$ \\
\hline \multirow[t]{5}{*}{ Animals } & $\begin{array}{l}\text { Animal categories (bovine, } \\
\text { caprine, ovine, asine, } \\
\text { cameline, equine }\end{array}$ & $\%$ & $\begin{array}{l}\text { Monthly variation } \\
\text { e.g. for January: } \\
0.826 ; 0.091 ; 0.055 ; 0.024 ; 0.001 ; 0\end{array}$ \\
\hline & Animal stock (12 months) & Head number & $2893 ; 5288 ; 15626 ; 22537$ \\
\hline & & & $13874 ; 7832 ; 1191 ; 408$ \\
\hline & & & $3168 ; 2835 ; 2510 ; 3348$ \\
\hline & Grazing area & ha & 5000 \\
\hline \multirow[t]{7}{*}{ GENDEC } & Inputs & Unit & Value \\
\hline & Soil temperature & ${ }^{\circ} \mathrm{C}$ & From STEP \\
\hline & Matrix potential & $\mathrm{MPa}$ & From STEP \\
\hline & Microbial assimilation efficiency & & 0.6 \\
\hline & Carbon pool & $\mathrm{gC}$ & From STEP \\
\hline & Microbial death rate & & 0.2 \\
\hline & $\begin{array}{l}\mathrm{N} / \mathrm{C} \text { (6) labile compounds, } \\
\text { holocellulose, resistant } \\
\text { compounds, dead and living } \\
\text { microbial biomass, nitrogen pool }\end{array}$ & & $10 ; 1000 ; 34 ; 8 ; 25 ; 9$ \\
\hline \multirow[t]{8}{*}{ NOFlux } & Inputs & Unit & Value \\
\hline & Surface WFPS & $\%$ & From STEP soil moisture \\
\hline & Surface soil temperature & ${ }^{\circ} \mathrm{C}$ & From STEP \\
\hline & Deep soil temperature & ${ }^{\circ} \mathrm{C}$ & From STEP \\
\hline & Wind speed & $\mathrm{ms}^{-1}$ & From meteorological forcing \\
\hline & $\mathrm{pH}$ & & 6.7 \\
\hline & Sand content & $\%$ & 91.2 \\
\hline & Mineral nitrogen & $\mathrm{g}(\mathrm{N}) \mathrm{m}^{-2}$ & From GENDEC \\
\hline
\end{tabular}


Soil moisture and temperature, wind speed, $\mathrm{pH}$, sand\%

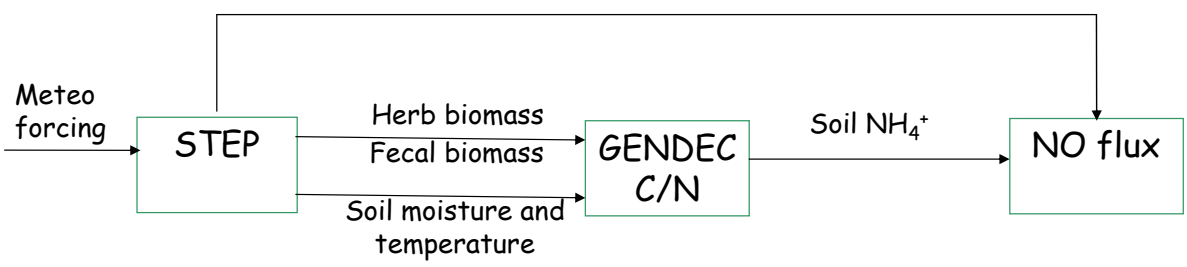

Schematic representation of NO flux modeling coupled to STEP-GENDEC

Figure 1. Schematic view of links between the STEP, GENDEC and NO emission models.

are controlled by the balance between total photosynthetic inputs expressed by the gross photosynthesis and total outputs due to respiration losses and senescence. Dry biomass results from the senescence of green material, minus litter production, ingestion by animals and burned biomass. Litter biomass accumulation is the result of dead material falling down on the soil, due to trampling and to climate conditions like rain, wind, and air temperature, minus litter burying and ingestion by animals, litter burning and litter decomposition due to insects, small mammals and climate conditions (rain kinetic energy, soil humidity, air temperature and wind). Green vegetation growth starts at seedling emergence with an initial above ground biomass. The date of emergence is estimated from the number of days required for germination when the moisture content of the soil surface layer is above wilting point. The quantity of faecal matter is calculated from the livestock total load given as input parameter.

The quantity of carbon in the soil is calculated from the total litter input (from faecal and herbal mass), which is $50 \%$ of the buried litter mass. The quantity of nitrogen in the soil is derived from the quantity of carbon using the $\mathrm{C} / \mathrm{N}$ ratio. A more detailed description of STEP can be found in Mougin et al. (1995), Tracol et al. (2006) and Jarlan et al. (2008). Information such as the quantity of faecal and herbal masses are transferred as inputs to GENDEC, the litter decomposition model.

\subsection{GENDEC}

GENDEC (for GENeral DEComposition) is a general, synthetic model, which aim is to examine the interactions between litter, decomposer microorganisms, microbial dynamics and $\mathrm{C}$ and $\mathrm{N}$ pools, and to explore the mechanisms of decomposition in arid ecosystems. The decomposition of buried litter by microorganisms is the first step of the GENDEC model, giving access to the mineral $\mathrm{C}$ and $\mathrm{N}$ pools of the ecosystem. GENDEC has been specifically developed to reproduce these processes in semi-arid ecosystems, where inputs of organic matter and soil moisture are low. The ultimate step, $\mathrm{C}$ and $\mathrm{N}$ mineralization, is fed by (1) decomposition of organic matter and (2) growth, respiration and death of microbes (microbial dynamics). The general modelling approach is based on fundamental decomposition processes. Six pools of $\mathrm{C}$ and $\mathrm{N}$ are used in this model, representing dead organic matter (labile materials with high $\mathrm{N}$ content and rapid decomposition rate, cellulose and related materials with an intermediate decomposition rate and very little associated $\mathrm{N}$, very slowly decomposing recalcitrant compounds with moderate levels of physically associated $\mathrm{N}$, and dead microbiota with high $\mathrm{N}$ content and rapid decomposition), living microbial biomass (final pool of organic matter), and soil $\mathrm{N}$ for the nitrogen submodel (Moorhead and Reynolds, 1991). The C / $\mathrm{N}$ ratio is different for each of these compartments, and is set to $10,1000,34,8,25$ and 9 respectively for labile compounds, holocellulose, resistant compounds, dead microbial biomass, living microbial biomass and nitrogen pools, based on Moorhead and Reynolds (1991) and experimental results from the Agoufou site detailed below. Flows between these pools are driven by empirical relationships according to characteristics of the microbial community. Climatic parameters such as soil moisture and soil temperature are important drivers for $\mathrm{C}$ and $\mathrm{N}$ dynamics. The model describes the processes underlying the interactions between $\mathrm{C}$ substrate, principal decomposers and nutrients that ultimately result in mineralization. Decomposition and microbial metabolic rates increase with increasing moisture availability (at least until saturation leads to anaerobic conditions) and with increasing temperature (at least at temperature below $30-40^{\circ} \mathrm{C}$ ). The dynamics of the soil $\mathrm{N}$ pool gives the net mineralization. The model emphasizes the association between $\mathrm{C}$ and $\mathrm{N}$ dynamics and microbial processes. Wetting drying events increase the turnover of microbial processes, stimulate $\mathrm{C}$ mineralization, and involve a short-term carbon dynamics since soil organic matter and nitrogen content are low. Microbial growth and respiration are functions of total carbon available, i.e. total $\mathrm{C}$ losses from the litter. Mineral $\mathrm{N}$ used to calculate NO release to the atmosphere is directly linked to mineral $\mathrm{C}$ used to calculate the respiration of microbes (i.e. $\mathrm{CO}_{2}$ release).

GENDEC is driven by organic matter input coming from four different boxes in STEP: buried litter (herbs and tree leaves), trees, faecal matter, and dry herb roots. It is also 
driven by soil temperature and soil water potential calculated in STEP. Input parameters include the assimilation efficiency and the microbial mortality rate (see Table 1). Finally, mineral nitrogen, total quantities of $\mathrm{C}$ and $\mathrm{N}$, respiration are obtained for each box (buried herbaceous litter, buried leaf trees, dry roots and faecal matter). The addition of these four contributions gives access to the total $\mathrm{C}$ and $\mathrm{N}$ in the soil. Organic carbon is assumed to be the sole source of energy and substrate for heterotrophic microbial growth. Organic matter mineralization driven by heterotrophic activity of soil microorganisms releases mineral nitrogen. This is the starting point for the calculation of nitrogen transformations in soils (Blagodatsky et al., 2011). The mineral nitrogen is then used as an input in the NOFlux model described below.

\subsection{NOFlux}

The NO biogenic emissions from soils is calculated with an emission algorithm derived from a neural network (Delon et al., 2007). The equation is detailed below. NO flux is a function of soil moisture, soil temperature at two depths (5 and $20-30 \mathrm{~cm}$ ), wind speed, soil $\mathrm{pH}$, sand percentage and fertilization rate (quantity of nitrogen given as input to the soil):

NOfluxnorm $=w_{24}+w_{25} \tanh (S 1)+w_{26} \tanh (S 2)+w_{27} \tanh (S 3)$,

where NOfluxnorm is the normalized NO flux. The normalization is used for all inputs and output to give them the same order of magnitude and facilitate the calculation process (Delon et al., 2007):

$$
\begin{aligned}
& S 1=w_{0}+\sum_{i=1}^{7} w_{i} x_{j, \text { norm }} \\
& S 2=w_{8}+\sum_{i=9}^{15} w_{i} x_{j, \text { norm }} \\
& S 3=w_{16}+\sum_{i=17}^{23} w_{i} x_{j, \text { norm }}
\end{aligned}
$$

where $j$ is 1 to 7 , and $x_{1, \text { norm }}$ to $x_{7, \text { norm }}$ correspond to the seven normalized inputs, as follows:

$j=1: \quad x_{1, \text { norm }}=c_{1}+c_{2} \times($ surface soil temperature $)$,

$j=2: \quad x_{2}$, norm $=c_{3}+c_{4} \times($ surface WFPS $)$,

$j=3: \quad x_{3, \text { norm }}=c_{5}+c_{6} \times($ deep soil temperature $)$,

$j=4: \quad x_{4, \text { norm }}=c_{7}+c_{8} \times($ fertilization rate $)$,

$j=5: \quad x_{5}$, norm $=c_{9}+c_{10} \times($ sand percentage $)$,

$j=6: \quad x_{6, \text { norm }}=c_{11}+c_{12} \times \mathrm{pH}$,

$j=7: \quad x_{7, \text { norm }}=c_{13}+x_{14} \times($ wind speed $)$.

Weights $w$ and normalization coefficients $c$ are given in Table 2:

WFPS $=$ Water Filled Pore Space.
Table 2. Weights and normalization factors for the calculation of NO flux.

\begin{tabular}{lrlrrr}
\hline$w 0$ & 0.561651794427011 & $w 14$ & 1.61126351888328 & $c 1$ & -2.453992 \\
$w 1$ & -0.48932473825312 & $w 15$ & 0.134088164903734 & $c 2$ & 0.142680 \\
$w 2$ & -0.53521035872982 & $w 16$ & -0.21261983875851 & $c 3$ & -4.609693 \\
$w 3$ & 0.506600069632212 & $w 17$ & 0.901773966331639 & $c 4$ & 0.115964 \\
$w 4$ & -0.784867014304196 & $w 18$ & -1.18779902340853 & $c 5$ & -2.717366 \\
$w 5$ & 0.283241716518431 & $w 19$ & 1.23132977162784 & $c 6$ & 0.163039 \\
$w 6$ & 0.132539461337082 & $w 20$ & -2.62451302093078 & $c 7$ & -0.364632 \\
$w 7$ & -0.008396615495977 & $w 21$ & -0.27778477919531 & $c 8$ & 5.577532 \\
$w 8$ & -1.62075908632141 & $w 22$ & 0.413060247967231 & $c 9$ & -1.535199 \\
$w 9$ & 0.638173941854311 & $w 23$ & -0.56046255255612 & $c 10$ & 0.054909 \\
$w 10$ & 3.88469485689393 & $w 24$ & 0.499562769416134 & $c 11$ & -25.554238 \\
$w 11$ & -0.942985468044301 & $w 25$ & -1.23876483956298 & $c 12$ & 3.158129 \\
$w 12$ & -0.862455616914003 & $w 26$ & -1.41295235373665 & $c 13$ & -1.182905 \\
$w 13$ & -2.68040193699105 & $w 27$ & -1.20659105237301 & $c 14$ & 0.614317 \\
& & & & $c 15$ & 3.903007 \\
& & & & $c 16$ & 9.205080 \\
\hline
\end{tabular}

The resulting NO flux is obtained after de-normalization of NOfluxnorm (NOFlux $=x_{15}+x_{16} \times$ NOfluxnorm).

A CRF is applied to the NO flux. The CRF ranges between 1 (no reduction because no vegetation, $\mathrm{LAI}=0$ ) and 0.83 $(\mathrm{LAI}=1.8$ at the most, Mougin et al., 2014). Considering the CRF applied, the maximum quantity of $\mathrm{N}$ re-deposited above canopy during the wet months when LAI is at its maximum is negligible compared to the total $\mathrm{N}$ input from faecal, herbal and root masses. Indeed, in the data used in this work, the proportion of $\mathrm{N}$ re-deposition compared to total $\mathrm{N}$ input ranges between 0.24 and $1.5 \%$, depending on the year.

In this study, we use a new approach to calculate the fertilization rate (this input was given as constant in the previous versions of the algorithm). This approach is based on the one of Potter et al. (1996), who have developed an extended version of the CASA (Carnegie Ames Stanford) model, where potential emission of total nitrogen trace gases $\left(\mathrm{N}_{\mathrm{T}}=\mathrm{NO}+\mathrm{NO}_{2}+\mathrm{N}_{2} \mathrm{O}+\mathrm{N}_{2}\right)$ at the soil surface is treated as a given percentage $(2 \%)$ of gross mineralized nitrogen at any given time step (this corresponds to the definition of the emission factor). This version of the simple conceptual model is not designed to distinguish between nitrification and denitrification as sources of $\mathrm{N}$ gases. In order to adapt this approach to our own study, we made the assumption that the sandy soil texture in Agoufou favours predominantly aerobic conditions and subsequently nitrification processes ( $\mathrm{Li}$ et al., 2000; Blagodatsky et al., 2011). Furthermore, the WFPS remains below $20 \%$ (volumetric soil moisture below $10 \%$ ), and according to Davidson (1991) the total oxidized N emitted would be composed of 95 to $100 \%$ of NO.

In the present work, we have adapted the concept developed in CASA in a different way: the fertilization rate (i.e. $\mathrm{N}$ entering the soil and further available for $\mathrm{NO}$ emission) is $2 \%$ (same percentage as in Potter et al., 1996) of the mineral $\mathrm{N}$ content in the soil (which depends both on $\mathrm{N}$ input and $\mathrm{N}$ content). The mineral $\mathrm{N}$ is obtained from STEP-GENDEC calculations. The main difference between the Potter et al. (1996) approach and the one of this study is that the NO 
emission is now modulated by additional parameters such as $\mathrm{pH}$ and wind speed, as well as soil moisture and temperature which have an impact on both mineralization and emission. When soil moisture is too low, microbial respiration is blocked in the model, microbial dynamics is frozen, and mineralization is stopped. If the value of mineral $\mathrm{N}$ is 0 , a minimum value of $0.01 \mathrm{~g} \mathrm{~m}^{-2}$ is applied as a first guess in the NOFlux model to avoid null values of $\mathrm{NO}$ emission. Indeed, very little is known about mineral $\mathrm{N}$ dynamics and subsequent NO emission at low soil moisture, but experimental studies show low emission even during the dry season (Scholes et al., 1997).

The principal advantage of this NO parametrization is to depend on different factors at two levels. The first level concerns climatic impacts and environmental parameters, such as precipitations, soil texture and $\mathrm{pH}$, temperatures, wind speed, and the second level concerns intrinsic processes of $\mathrm{N}$ turnover in the soil, through the organic matter degradation from vegetation and livestock, and the microbial dynamics. The majority of the first-level variables are easily available on site or/and from atmospheric model reanalysis and global databases; the second level is a sophistication of the model, making it possible to add biotic processes in this parametrization of $\mathrm{NO}$ emission.

\section{Results and discussion}

Several parameters, included in the NO emission model, play an important role in modulating emission. These parameters can be classified in two categories: physical parameters (soil moisture and temperature, wind speed, sand percentage) which affect substrate diffusion and oxygen supply in the soil and influence the microbial activity (Skopp et al., 1990), and biogeochemical parameters ( $\mathrm{pH}$ and fertilization rate related to $\mathrm{N}$ content). In this section, we discuss the reliability of the simulated variables, in order to assess the robustness of the simulated NO flux.

\subsection{Soil moisture}

Soil moisture has a strong influence on NO emission from soils, particularly in hot and dry regions, at the global, regional or local scale (Williams et al., 1992; Yienger and Levy, 1995; Meixner et al., 1997; Hartley and Schlesinger, 2000; Yan et al., 2005; Feig et al., 2008; Hudman et al., 2012). This variable needs to be well reproduced by the model in order to calculate reliable NO release. Volumetric soil moisture is calculated by STEP at different soil layers, using a tipping bucket approach. Figure 2 shows the volumetric soil moisture calculated by STEP between 0 and $2 \mathrm{~cm}$ from 2004 to 2008, compared to the volumetric soil moisture measured at Agoufou at $5 \mathrm{~cm}$ depth in 2005, 2006, 2007 and 2008. From 2006 to 2008, these measurements are actually an average of three data sets from soil moisture probes oper- ating at the top, middle and bottom locations of dune slopes. In 2005, only bottom slope data were available.

The comparison between STEP and measurements in Fig. 2 is not direct, because depths are not exactly equivalent. Indeed, it is in general quite difficult to have in situ soil moisture measurements in the very first soil centimetres especially over sandy soils. Despite this, the comparison gives satisfying results from 2005 to 2008. In the surface layer, the measurements reach 10 to $12 \%$ during summers and show lower values during the dry season than those calculated by STEP. A threshold at $8 \%$ is observed on the STEP plot. This value corresponds to the field capacity calculated by STEP. In reality, this theoretical value may be overstepped during short periods of time after a rainfall event, and water is not systematically transferred to the layer underneath. In the model, when the field capacity is reached, the excess water is transferred to the second layer, between 2 and $30 \mathrm{~cm}$. The higher soil moisture peaks observed in the measurements as compared to STEP may be also due to the deeper soil depth at which the measurements are taken. For all years, the model is consistent and correctly reproduces the temporal dynamics - the increase and decrease of the soil moisture are well in phase, and the filling and emptying of the surface layer is reasonably well represented. The determination coefficient between model and measurements $R^{2}$ is 0.70 for the considered period (5 years).

\subsection{Soil temperature}

Soil temperature is also an important variable for modelling NO emissions from soils. In tropical regions, emissions are mostly driven by soil moisture, but temperature influence has to be taken into account, especially during the dry season when soil moisture is very low (Butterbach-Bahl et al., 2004b; Yao et al., 2010). Figure 3 shows the soil temperature calculated in the two first STEP layers and compared to measurements at 5 and $30 \mathrm{~cm}$ at Agoufou from 2005 to 2008 . Temperatures at both levels are needed in the NOFlux model. The seasonal cycle is well reproduced by the model, with some missing high-frequency variations due to rain events during the wet season. The determination coefficient $R^{2}$ between the simulated and measured temperatures in the surface layer is 0.86 , and 0.82 in the $30 \mathrm{~cm}$ layer, showing a good representation of temperature at both levels in the model.

\subsection{Aboveground and litter vegetation}

The temporal variation of the green living biomass, dry standing biomass (or standing straw), surface litter and buried litter is simulated and compared to measurements at Agoufou (except for buried litter because no measurements are available). Green biomass begins to increase between 20 and 25 June for years 2004 and 2005, and between 10 and 15 July for years 2006 to 2008 , when the surface soil mois- 


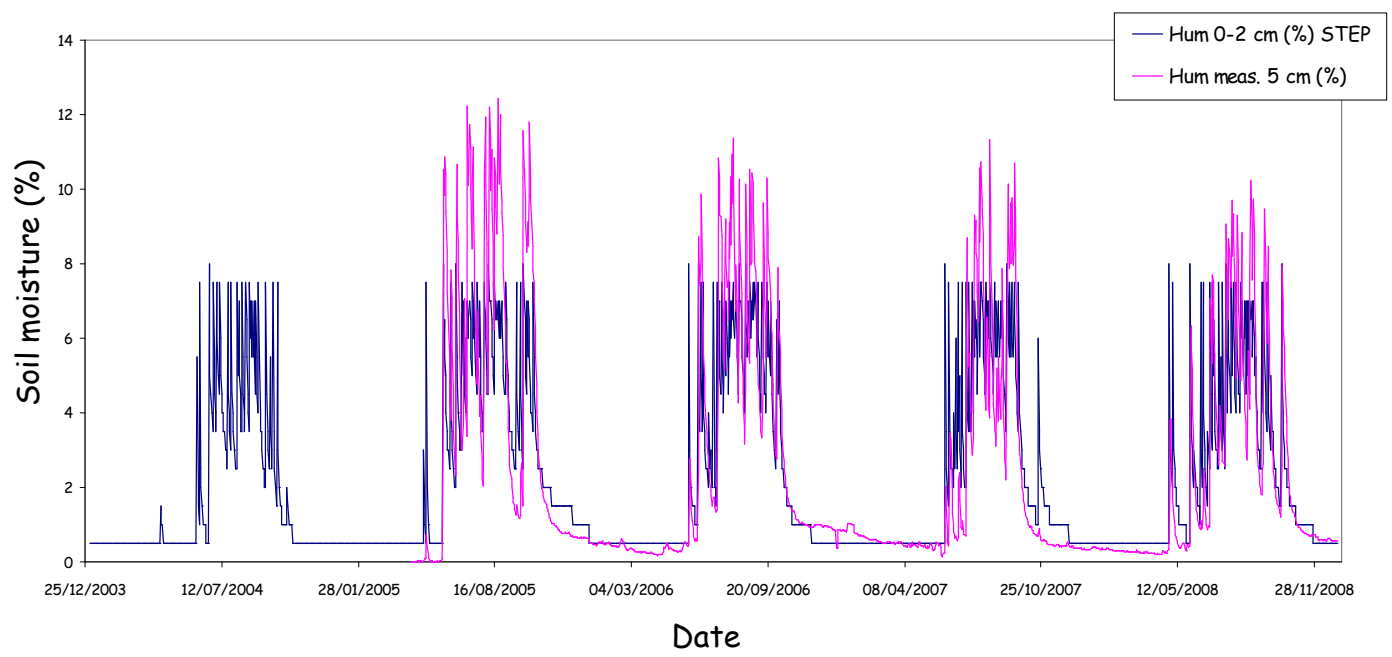

Figure 2. Soil moisture calculated by STEP at the surface layer $(0-2 \mathrm{~cm})$ in blue, mean soil moisture measured at $5 \mathrm{~cm}$ in pink, for years 2004 to 2008 at Agoufou.

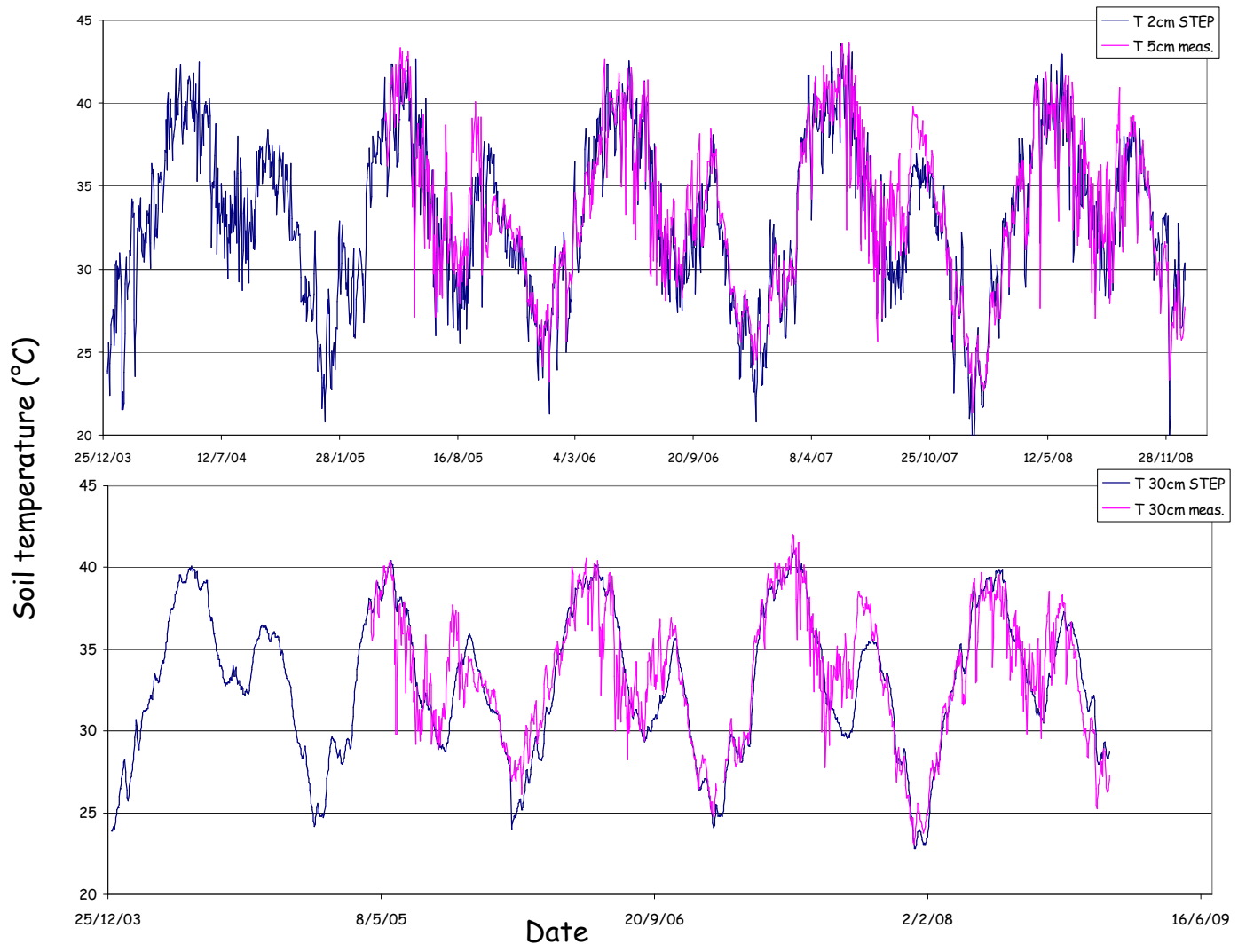

Figure 3. (a) Soil temperature measured at $5 \mathrm{~cm}$ at the low slope station (in pink), soil temperature simulated at the surface layer in blue; (b) soil temperature measured at $30 \mathrm{~cm}$ at the low slope station (in pink), soil temperature simulated at the second layer (2-30 cm) in blue, for years 2004 to 2008 at Agoufou.

ture is above the wilting point during 5 consecutive days (green in Fig. 4). In 2004, 2005, 2006, 2007 and 2008 respectively, the cumulative rain is 191, 418, 376, 286 and $227 \mathrm{~mm}$. The maximum of green biomass simulated by STEP is $80,205,192,161$ and $104 \mathrm{~g}$ (d.m.) $\mathrm{m}^{-2}$ (d.m. $=$ dry matter), when the respective measurements give $47,224,174$, 150 and $82 \mathrm{~g}\left(\mathrm{~d} . \mathrm{m}\right.$.) $\mathrm{m}^{-2}$ in 2004, 2005, 2006, 2007 and 2008. In 2004, two distinct growing phases are simulated, cor- 
roborated by measurements. Indeed, the first green biomass growth is interrupted due to a lack of rainfall, and starts again later in the season. The maximum simulated green biomass value seems to be slightly late in 2006 and 2007, and early in 2008, compared to measurements, whereas the seedling emergence is correctly simulated for these years. In 2008, the quantity of precipitation is lower, but the soil moisture is sufficient to trigger seedling emergence in the model. Overall, simulations and measurements are in good agreement with $R^{2}=0.72$ for green biomass for the 5 years.

The change over time of the herbaceous standing mass is driven by mechanical and biological degradation, influenced, among other causes, by livestock grazing. Forage consumption and trampling by livestock have major effects on herbage offtake, decay and decomposition including seed dispersal (Tracol et al., 2006). The STEP model allows the drying from green to dry standing biomass, and the degradation of the dry biomass by livestock. The minimum value for the initialization of dry standing biomass in 2004 is $10 \mathrm{~g}$ (d.m.) $\mathrm{m}^{-2}$. The increase of the senescent aboveground biomass at the end of the wet season is well reproduced by the simulation (light blue in Fig. 4). $R^{2}$ between simulations and measurements is 0.56 for dry standing biomass for the 5 years of simulation. The maximum of dry standing biomass is underestimated in 2006 and 2008 and well reproduced in 2004 (despite a particular feature) and 2007. No measurements were available for year 2005 .

The minimum value for the initialization of the surface litter in 2004 (red in Fig. 4) is $30 \mathrm{~g}$ (d.m.) $\mathrm{m}^{-2}$. The maximum value is encountered in December-January (end of November in 2004). Litter decay is sharper in the measurements than in the simulation, with minimum occurring in the middle of the wet season. $R^{2}$ between simulations and measurements is 0.5 for litter for the 5 years of simulation.

The evolution of simulated buried litter (dark blue in Fig. 4 is closely linked to that of surface litter. The first days of rain induce a sharp decrease of buried litter, which is rapidly decomposed. The minimum is observed in September (August in 2004), when it begins to increase again with the surface litter accumulation. That accumulation feeds the $\mathrm{C}$ and $\mathrm{N}$ pools, and is the $\mathrm{N}$ resource for soil mineral $\mathrm{N}$ and $\mathrm{N}$ losses to the atmosphere.

The evaluation of the model in terms of vegetation dynamics, quantity and production of surface litter seems to be reliable, despite time lags in some cases. Therefore, the quantity of organic matter (via the buried litter) likely to be degraded and to produce $\mathrm{N}$ in the soil can be considered as correctly reproduced by the model.

\subsection{N content in the soil}

The $\mathrm{N}$ content calculated by the model has been compared to $\mathrm{N}$ content analysis made on 35 different soil samples in Agoufou (sampled in July 2004). Results from soil samples give a mean total $\mathrm{N}$ content of $0.20 \pm 0.14 \mathrm{~g} \mathrm{~kg}^{-1}$ (or
$0.02 \%$ ), with a mean $\mathrm{C} / \mathrm{N}$ ratio of $9.80 \pm 1.11$. Diallo and Gjessing (1999) have mentioned $0.011 \%$ of total $\mathrm{N}$ in sandy soils of the Gourma region, where Agoufou is situated. However, the few studies performed on arid or semi-arid soils showed that high microbial metabolism and high turnover rates of little nutrients might be major explanatory factors of the observed NO fluxes (Meixner and Yang, 2006 and references therein). In the model, the total soil $\mathrm{N}$ content is the sum of mineral $\mathrm{N}$, organic $\mathrm{N}$ and microbial $\mathrm{N}$ (Fig. 5). To convert the model output in $\mathrm{g}(\mathrm{N}) \mathrm{m}^{-2}$ to percentage, we assume a density of $1500 \mathrm{~kg} \mathrm{~m}^{-3}$ for the soil, according to De Rosnay et al. (2009), and we apply this value to the first $2 \mathrm{~cm}$ of the soil (first layer in the model). Yearly means range from $0.016 \%$ in 2004, $0.023 \%$ in $2005,0.030 \%$ in 2006 to $0.035 \%$ in 2007 and 2008 . To compare directly to measurements, we have calculated the average for the 15 first days of July in the model, and obtained $0.020 \%$ in 2004, $0.022 \%$ in $2005,0.031 \%$ in 2006 to $0.037 \%$ in 2007 and 2008, values that are representative of the beginning of the wet season, and very close to measurements at the same dates. It is rather difficult to find direct comparisons to ensure the model initializations in terms of $\mathrm{N}$ content and $\mathrm{N}$ dynamics in the region of the Sahel. However, some studies like De Bruin et al. (1989) and Krul et al. (1982) show from incubation results that after the long dry season the soil contains approximately $14 \mathrm{~kg}(\mathrm{~N}) \mathrm{ha}^{-1}$ (approximately $0.005 \%$, lower than our results) in the first $10 \mathrm{~cm}$, and the nitrogen flush after the intensive first rains is about 7 to $8 \mathrm{~kg}(\mathrm{~N}) \mathrm{ha}^{-1}$. Our results in the next section imply the same kind of emissions at the beginning of the wet season, which gives confidence on the robustness of the $\mathrm{N}$ dynamics reproduced by GENDEC.

\subsection{NO emission from soil to the atmosphere}

\subsubsection{Seasonal and yearly cycle of NO emissions}

As explained above, the quantity of $\mathrm{N}$ due to the decomposition of buried litter and faecal biomass and to the microbial turnover is calculated in GENDEC, and therefore used to parametrize the NO emissions from soil (see Fig. 6 for 2004 to 2008). Yearly and wet season (from 1 June to 30 September) averages are reported in Table 3 . The largest emission (up to $24 \mathrm{ng}(\mathrm{N}) \mathrm{m}^{-2} \mathrm{~s}^{-1}$ ) occurs at the beginning of the wet season. Indeed, as shown in Fig. 6, the first rains induce a sharp increase in soil surface moisture until saturation, followed by a subsequent drying out of the surface layer until the following rain event. The organic matter, brought by the buried litter, is suddenly decomposed when the soil moisture is sufficient, and produces a NO pulse to the atmosphere. This kind of process has already been highlighted by e.g. Butterbach-Bahl et al. (2004b) in a rain forest where a huge amount of litter that had accumulated during the long-lasting dry period of the year before was intensively decomposed with the onset of rainfall. 


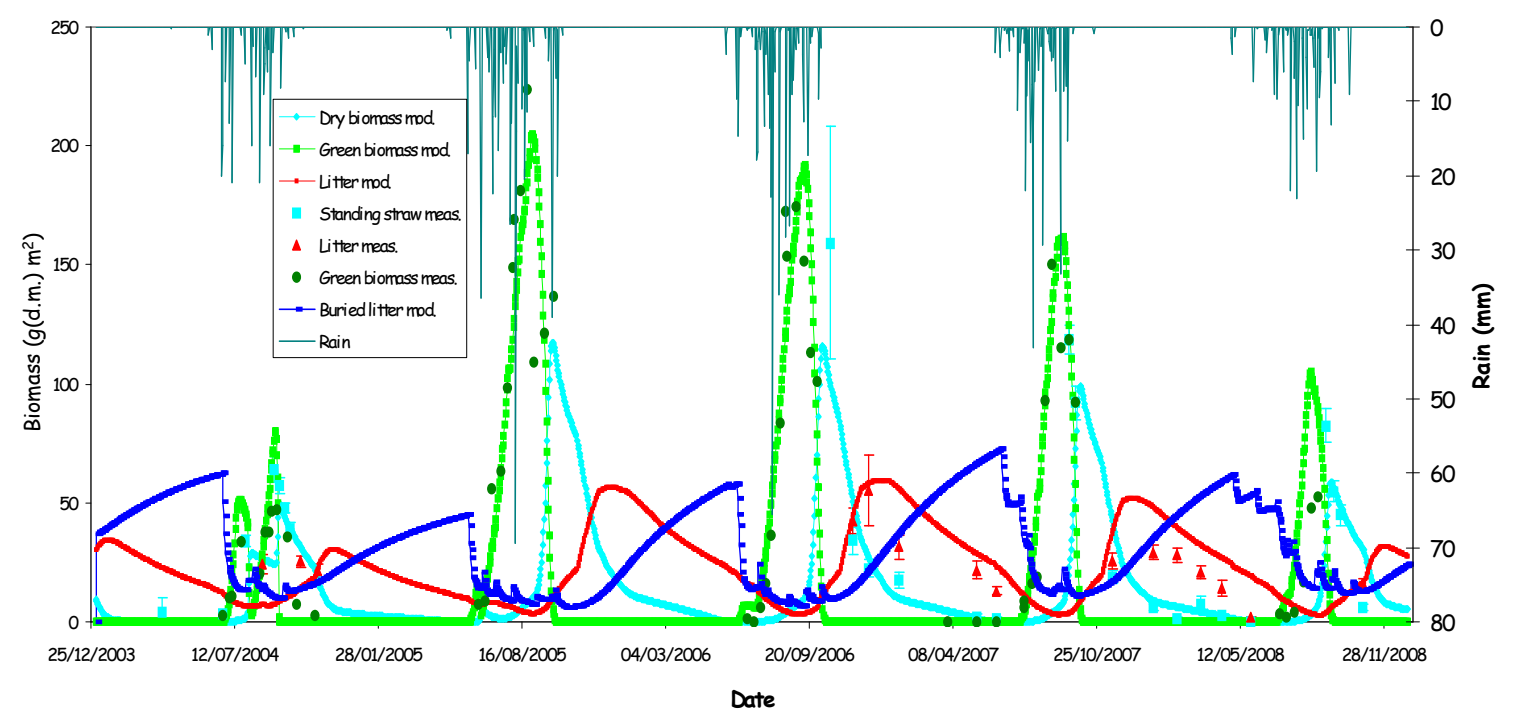

Figure 4. Green biomass in green, dry biomass in light blue, surface litter in red, buried litter in dark blue (line for the model, dots for measurements), in $\mathrm{g}\left(\mathrm{d} . \mathrm{m}\right.$.) $\mathrm{m}^{-2}$. Standard deviations are indicated for the measurements. Rain in blue-grey in mm, for years 2004 to 2008 at Agoufou.

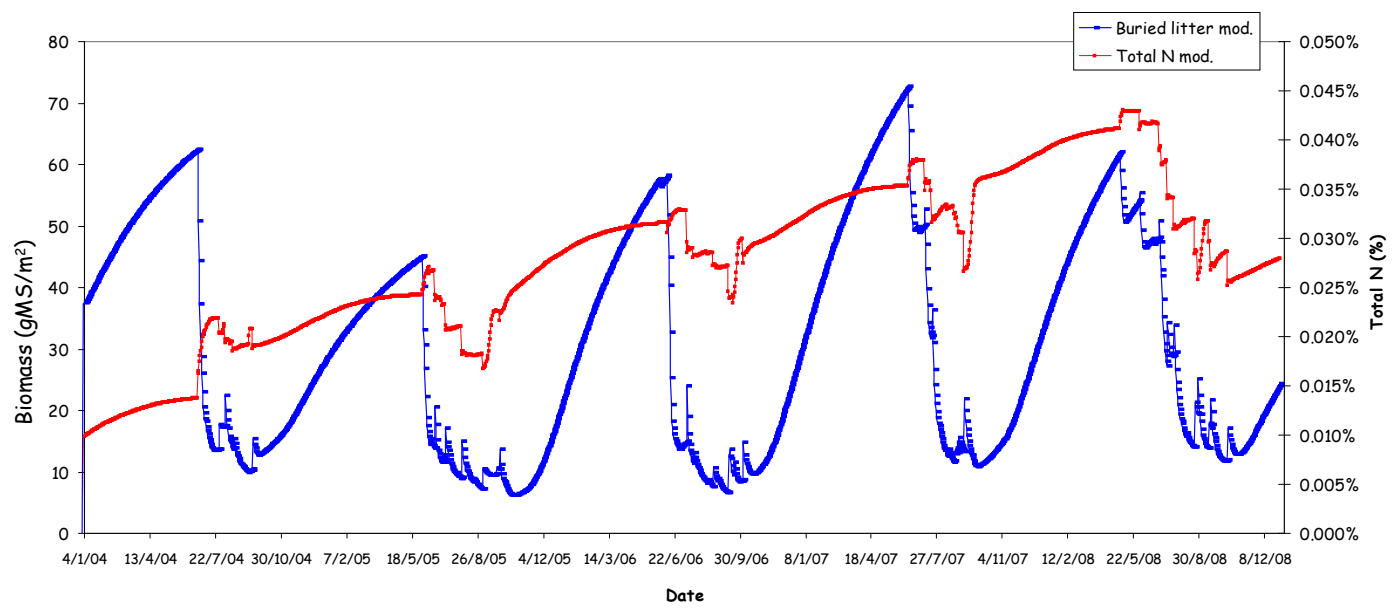

Figure 5. Simulated buried litter in $\mathrm{g}(\mathrm{d} . \mathrm{m}.) \mathrm{m}^{-2}$ in dark blue and total $\mathrm{N}$ content in the soil in \%, for years 2004 to 2008 at Agoufou.

After these peaks, in the core of the rain season, though additional rainfall events, less $\mathrm{N}$ is released to the atmosphere and NO emissions decrease. Figure 7 shows the mineral N behaviour together with the rainfall amount. First rains and rains after a short break lead to a sharp increase in mineral $\mathrm{N}$ content (in $\mathrm{g} \mathrm{m}^{-2}$ ), whereas frequent rains in the core of the wet season do not stimulate mineral $\mathrm{N}$ in the same proportion. Furthermore, Krul et al. (1982) have shown that when the soil moisture is sufficient to allow the growth of the vegetation, the mineral $\mathrm{N}$ in the soil is taken by the plants (not numerically represented in this version of the model), in competition with the assimilation by microbes, and therefore less released to the atmosphere.

After the end of the wet season, when the maximum of green biomass is reached, the vegetation starts to dry out while still standing, then falls on the surface and begins to decompose since the soil surface moisture is still relatively high. The vegetation decomposition at that moment is responsible for the peak of emission observed in the late wet/early dry season. Afterwards, the soil surface moisture decreases, leading to low NO emissions. During the dry season, emissions are reduced, but still present, and mostly driven by surface temperature. Actually, the influence of temperature also exists during the wet season at a diurnal time step (as already highlighted by Ludwig et al., 2001 for different data), but is dominated by soil moisture effect. This temperature effect is better described in the next section.

Despite the strong dependance of NO fluxes on soil moisture, the total rainfall amount in a year does not appear to be essential for the amplitude of the fluxes. Indeed, though 
Table 3. Comparison of experimental and simulated NO fluxes (daily scale) during various wet and dry seasons in dry savanna sites. The model used is indicated in parentheses. No model specified means experimental data. For yearly means, values are also indicated in $\mathrm{kg}(\mathrm{N}) \mathrm{ha}^{-1} \mathrm{yr}^{-1}$ in parentheses.

\begin{tabular}{|c|c|c|c|}
\hline Site name & NO flux $\left(n g(N) m^{-2} s^{-1}\right)$ & Period & Reference \\
\hline Banizoumbou & $6.09 \pm 2.63$ & Wet season 1992 & Le Roux et al. (1995) \\
\hline South Africa & $5.4-7.9$ & Wet season 1993 & Otter et al. (1999) \\
\hline Chihuahuan desert & 2.41 & Watered soils 1993 & Hartley and Schlesinger (2000) \\
\hline Agoufou & $6.69 \pm 2.44$ & Wet season 2004 & Delon et al. (2007), This work \\
\hline Agoufou & $2.28 \pm 0.79$ & Wet season 2005 & This work \\
\hline Agoufou (STEP) & $3.36 \pm 3.17$ & Wet season 2004 & This work \\
\hline Agoufou (STEP) & $4.88 \pm 4.28$ & Wet season 2005 & This work \\
\hline Agoufou (STEP) & $4.95 \pm 4.82$ & Wet season 2006 & This work \\
\hline Agoufou (ISBA) & $7.99 \pm 3.61$ & Wet season 2006 & Delon et al. (2010) \\
\hline Agoufou (STEP) & $4.91 \pm 4.53$ & Wet season 2007 & This work \\
\hline Agoufou (STEP) & $5.48 \pm 5.23$ & Wet season 2008 & This work \\
\hline Agoufou (STEP) & $1.46 \pm 0.51$ & Dry season 2004 & This work \\
\hline Agoufou (STEP) & $1.67 \pm 0.59$ & Dry season 2005 & This work \\
\hline Agoufou (STEP) & $1.62 \pm 0.64$ & Dry season 2006 & This work \\
\hline Agoufou (STEP) & $1.56 \pm 0.51$ & Dry season 2007 & This work \\
\hline Agoufou (STEP) & $1.80 \pm 1.13$ & Dry season 2008 & This work \\
\hline Agoufou (STEP) & $\begin{array}{c}2.09 \pm 2.06 \\
(0.66 \pm 0.65)\end{array}$ & Year 2004 & This work \\
\hline Agoufou (STEP) & $\begin{array}{c}2.73 \pm 2.92 \\
(0.86 \pm 0.92)\end{array}$ & Year 2005 & This work \\
\hline Agoufou (STEP) & $\begin{array}{c}2.73 \pm 3.23 \\
(0.86 \pm 1.02)\end{array}$ & Year 2006 & This work \\
\hline Agoufou (STEP) & $\begin{array}{c}2.69 \pm 3.08 \\
(0.85 \pm 0.97)\end{array}$ & Year 2007 & This work \\
\hline Agoufou (STEP) & $\begin{array}{c}3.04 \pm 3.58 \\
(0.96 \pm 1.13)\end{array}$ & Year 2008 & This work \\
\hline
\end{tabular}

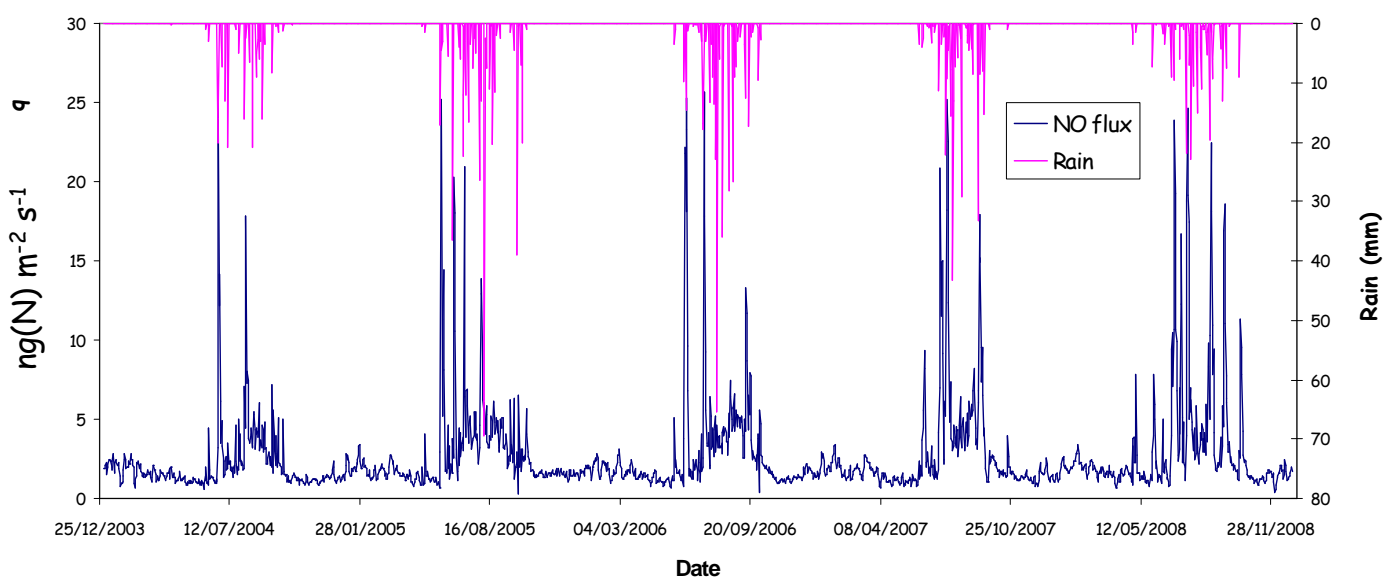

Figure 6. Simulated NO flux in $\mathrm{kg}(\mathrm{N}) \mathrm{ha}^{-1} \mathrm{yr}^{-1}$ and rain in mm, for years 2004 to 2008 at Agoufou.

2008 rainfall amount is less important than in 2005, 2006 and 2007, the annual and wet season NO flux averages are larger in 2008. This is not the case in 2004, and could be attributed to the fact that 2008 wet season begins earlier and ends later than in the other years, allowing more efficient and more frequent pulse events.

Some wet season measurements performed at Agoufou in July 2004 and August 2005 are reported in Table 3. The model underestimates the measurements in 2004 (10 days 


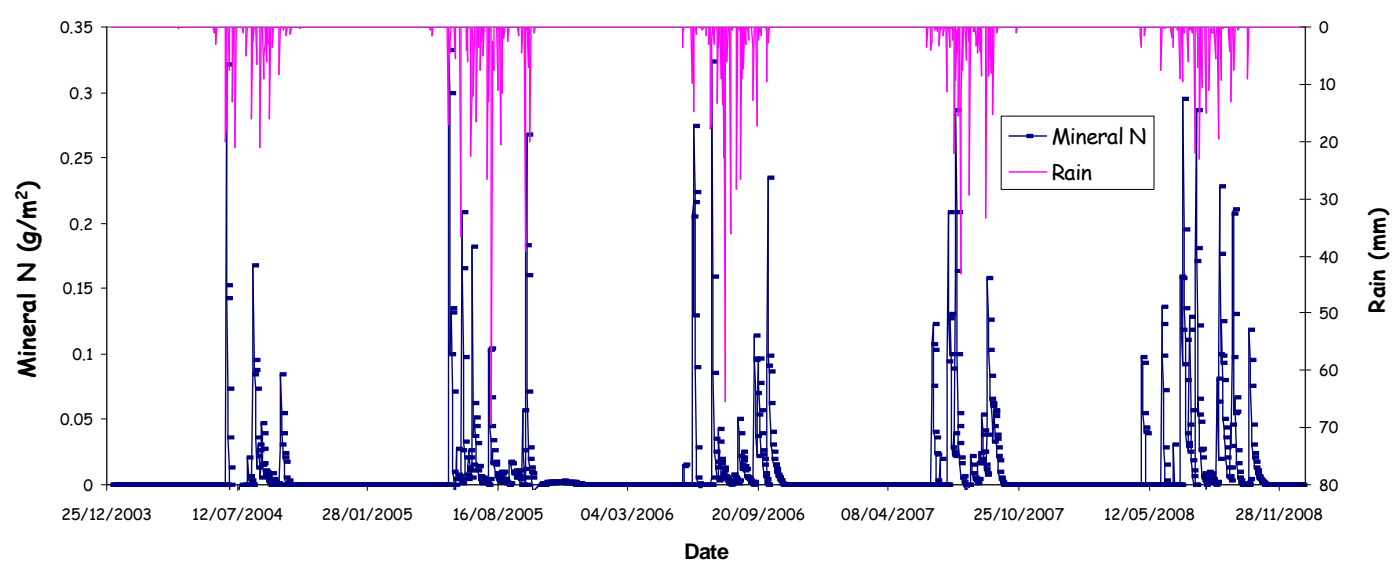

Figure 7. Simulated mineral $\mathrm{N}$ in $\mathrm{g} \mathrm{m}^{-2}$ and rain in $\mathrm{mm}$ for years 2004 to 2008 at Agoufou.

in July), and overestimates them in 2005 (3 days in August). However, modelled fluxes are in the range of measured fluxes. In Table 3, they are compared to other measurements made in other types of semi-arid ecosystems, and to wet season measurements in Banizoumbou (Niger), situated in a dry savanna site and presenting the same type of vegetation (Delon et al., 2012). Data from this study are also compared to other simulations done with the ISBA model (Interactions Soil Biosphere Atmosphere) used to simulate emission and deposition $\mathrm{N}$ fluxes in dry savannas in a previous study (Delon et al., 2010 and Delon et al., 2012), where the $\mathrm{N}$ input (fertilization rate) was constant in time, and equivalent to $5.5 \mathrm{~kg}(\mathrm{~N}) \mathrm{ha}^{-1} \mathrm{yr}^{-1}\left(17.4 \mathrm{ng}(\mathrm{N}) \mathrm{m}^{-2} \mathrm{~s}^{-1}\right)$.

These results show that the coupled STEP-GENDEC-NO model gives fluxes in the order of known experimental or simulated data, while not exactly equivalent to measurements at the Agoufou site in 2004 and 2005. Several studies have shown different ranges of NO fluxes, but always with a strong link to soil moisture, especially in tropical regions where distinct dry and wet seasons exist, and where large pulses of NO emissions occur at the onset of the rainy season (Ludwig et al. (2001), Otter et al. (1999), Meixner et al. (1997), Yang and Meixner (1997), Meixner and Yang (2006), Van Dijk et al. (2002) as examples in tropical and semi-arid regions). As a comparison, Butterbach-Bahl et al. (2004b) found average fluxes of $57 \mathrm{ng}(\mathrm{N}) \mathrm{m}^{-2} \mathrm{~s}^{-1}$ in tropical forests soils at the transition between dry and wet season, where the quantity of decomposed litter is far greater than in dry savanna sites of the Sahel, and where the nutrient content of the soil is far larger, since semi-arid soils are generally nutrient poor.

The ratios of fluxes from wet to dry seasons in this study are 2.3, 2.9, 3.0, 3.1 and 3.0 respectively for the years 2004, 2005, 2006, 2007, 2008, in the (lower) range of what has been reported in the literature (Meixner and Yang, 2006), but showing undoubtedly the difference between the two periods in terms of emission.

\subsubsection{Sensitivity tests}

Several sensitivity tests have been performed in the NOFlux model to highlight the effects of soil temperature, soil humidity and mineral $\mathrm{N}$ content on the NO flux to the atmosphere. The sensitivity of NO emission to deep soil temperature and wind speed will not be shown here, because their influence on NO emission is less important. In the first example (Fig. 8), soil moisture is set successively to a low (2\%) and a high $(10 \%)$ value, associated respectively with a low $\left(0.01 \mathrm{~g} \mathrm{~m}^{-2}\right)$ and a high $\left(0.1 \mathrm{~g} \mathrm{~m}^{-2}\right)$ value of mineral $\mathrm{N}$ content in the soil. The associated high and low values of mineral $\mathrm{N}$ with soil moisture have been chosen according to realistic outputs given by the GENDEC model (see Fig. 7), and corresponding to dry and wet season quantities. The results are shown for year 2006 only, to lighten the figures, because 2006 is a standard year in terms of pluviometry, and the same conclusions would appear anyway for the other years. When soil moisture is low and constant (associated with low and constant mineral $\mathrm{N}$ content), NO fluxes are only driven by soil temperature at high (diurnal) frequency. Pulses usually linked to soil moisture variation do not occur and the mean value of the flux remains low. When soil moisture is high (associated with a high value of mineral $\mathrm{N}$ content), the mean value of the flux is larger, directly resulting from high mineral $\mathrm{N}$ content. The seasonal cycle of fluxes is not correlated to the seasonal cycle of soil temperature, as already found by Meixner and Yang (2006) - low-frequency variation - whereas their diurnal cycle are correlated, in accordance with previous studies. As an example, Ludwig et al. (2001) have stated that soil temperature fluctuations can explain short-term variations of NO fluxes.

In the second example (Fig. 9), soil moisture and mineral $\mathrm{N}$ content are not forced; soil surface and bottom temperatures are set successively to both a low $\left(33\right.$ and $32^{\circ} \mathrm{C}$ respectively) and a high ( 48 and $47^{\circ} \mathrm{C}$ respectively) value, for the year 2006. These temperatures correspond to possible values encountered during the dry and wet seasons. At the beginning 


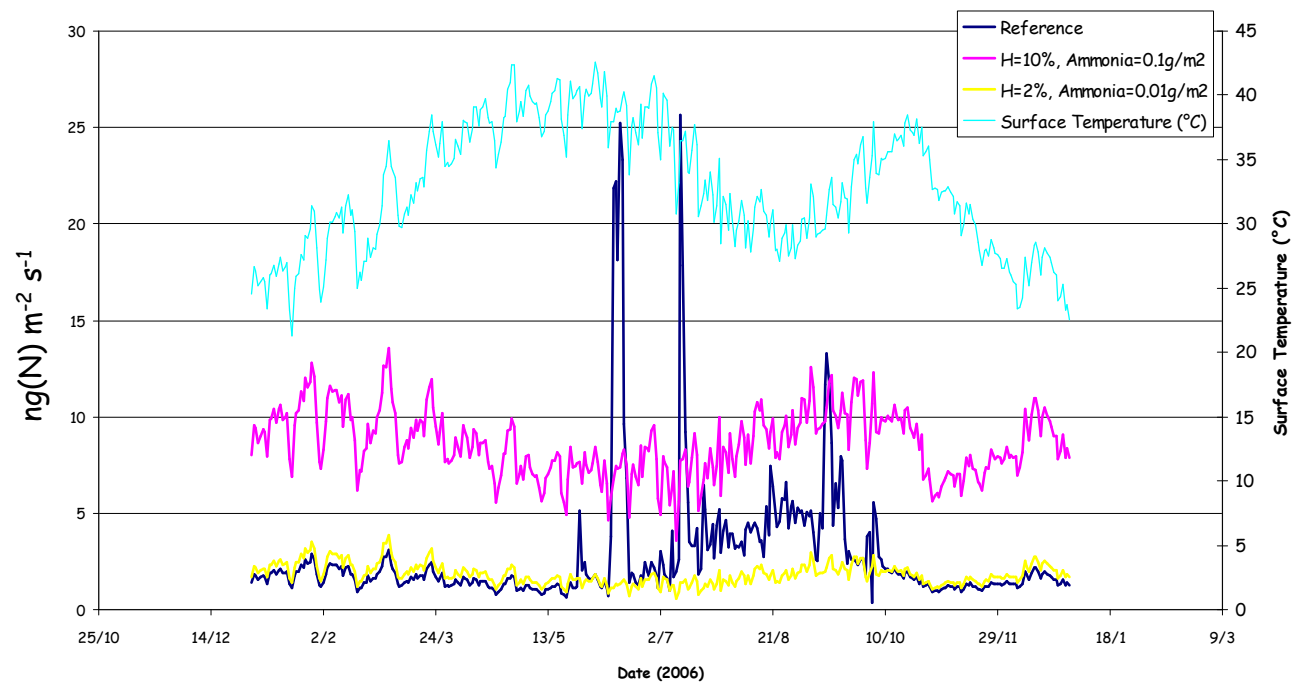

Figure 8. Sensitivity test. In dark blue: reference $\mathrm{NO}$ flux in $\mathrm{kg}(\mathrm{N}) \mathrm{ha}^{-1} \mathrm{yr}^{-1}$; in yellow: $\mathrm{NO}$ flux with $\mathrm{H}=2 \%$ and mineral $\mathrm{N}=0.01 \mathrm{~g} \mathrm{~m}{ }^{-2}$; in pink: NO flux with $\mathrm{H}=10 \%$ and mineral $\mathrm{N}=0.1 \mathrm{~g} \mathrm{~m}^{-2}$; in light blue: surface temperature in ${ }^{\circ} \mathrm{C}$, for year 2006 .

of the year, during the dry season, the soil moisture is low, and fluxes are constant if soil temperature is constant. During both seasons, the lowest NO fluxes are found for the highest values of soil temperature, even if differences are reduced between mean annual fluxes $\left(1.08\right.$ vs. $0.69 \mathrm{~kg}(\mathrm{~N}) \mathrm{ha}^{-1} \mathrm{yr}^{-1}$, i.e. 3.42 vs. $2.19 \mathrm{ng}(\mathrm{N}) \mathrm{m}^{-2} \mathrm{~s}^{-1}$ for $T=33$ and $T=48^{\circ} \mathrm{C}$ respectively) despite a large temperature difference $\left(15^{\circ} \mathrm{C}\right)$. Temperature effect on $\mathrm{NO}$ emissions has been studied in other circumstances, and is still under debate still no clear conclusion could be reached. Contrasting results have been found in tropical and temperate regions: most studies have shown that NO emissions increase with increasing temperature as reported for example in Martin et al. (1995), Meixner and Yang (2006) and Van Dijk and Meixner (2001); other studies do not find any clear tendency (Cardenas et al., 1994; Sullivan, 1996), while Butterbach-Bahl et al. (2004b) find a linear relationship during only certain periods of the year in a tropical rain forest. Temperature effect in our study is moderate in the dry season, and almost not visible in the wet season.

In addition, soil $\mathrm{pH}$ effects have also been tested (not shown here) within a reasonable range of $\mathrm{pH}$ from 6.1 to 8 . Pulse effects and modulation by soil temperature present the same feature as in the reference case, with a slight decrease of the base level when $\mathrm{pH}$ increases. Serça et al. (1994) and Yan et al. (2005) have also found the same kind of variation, with decreasing emissions while increasing $\mathrm{pH}$ in tropical soils.

Sensitivity tests of the NO emission model used in this study have already been explored in Delon et al. (2007) for the elaboration of the model. The most straightforward conclusion from these tests is that soil moisture is the main driver for NO fluxes in the particular conditions of semi-arid soils (with immediate effect on soil $\mathrm{N}$ content), modulated by soil temperature effect (mostly visible during the dry season) and adjusted by soil $\mathrm{pH}$ and wind effects.

\section{Limitations and uncertainties}

Estimating NO fluxes in semi-arid regions through modelling studies remains a difficult exercise, considering the scarcity of data. Uncertainties in the calculation of NO fluxes in the model are related to uncertainties on the main drivers of $\mathrm{NO}$ emission, i.e. soil moisture, and mineral N. Furthermore, the mineral $\mathrm{N}$ concentration in the soil is also driven by soil moisture. The uncertainty on the NO flux has been estimated at around $20 \%$ when calculated with the present algorithm (Delon et al., 2010). Despite the scarcity of validation flux measurements, and of data on $\mathrm{N}$ cycle in the soil, this work gives results that can be added to the existing knowledge on emission processes. Simulated fluxes are of the order of magnitude of previous measurements performed in the same semi-arid region. As mentioned in Davidson et al. (2000), a model based on regression parameters between NO emissions and nitrogen cycling in the ecosystem will have only order of magnitude prediction accuracy. The temporal variation of the quantity of live and dry biomass (straw and litter) has been accurately compared to measurements, but the case is different for the seasonal cycles of the $\mathrm{N}$ pools in the soil. Comparisons have been made with the available experimental data at a given time, but do not give access to the whole yearly cycle. The mineral $\mathrm{N}$ concentration in the soil used as input in the calculation of NO fluxes is set to zero by the model during the dry season because the respiration of microbes is blocked when soil moisture is too low. In this work it was set to a non-zero value to avoid null NO fluxes. This value should be moderated and readjusted according to experimental results of available nitrogen in the soil during the dry season.

While the STEP model was initially designed for 1-D simulations in well-documented study sites, it has also been re- 


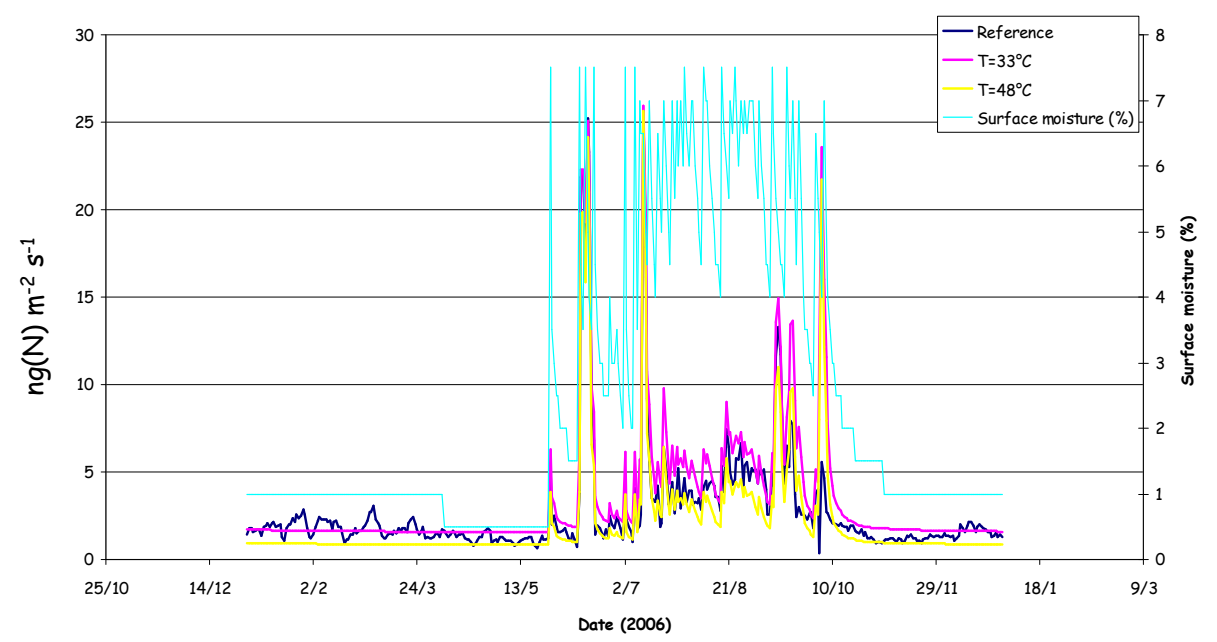

Figure 9. Sensitivity test. In dark blue: reference NO flux in $\mathrm{kg}(\mathrm{N}) \mathrm{ha}^{-1} \mathrm{yr}^{-1}$; in yellow: NO flux with $T=48^{\circ} \mathrm{C}$; in pink: $\mathrm{NO}$ flux with $T=33^{\circ} \mathrm{C}$; in light blue: surface moisture in $\%$, for year 2006 .

cently used at the regional scale in the Gourma region to produce maps of vegetation biomass by Jarlan et al. (2003), and in the Sahelian belt $\left(12^{\circ} \mathrm{N}-20^{\circ} \mathrm{N} ; 20^{\circ} \mathrm{W}-35^{\circ} \mathrm{E}\right)$ by Pierre et al. (2012) and Pierre et al. (2011), to estimate the amount of dust emissions in that region. The NO flux model has also been applied in the region of Niamey, Niger (Delon et al., 2008) to reproduce NO pulses at the beginning of the wet season, and their impact on ozone formation during the AMMA field campaign in 2006. Furthermore, it has been used at the regional scale in the Sahel (Delon et al., 2010) and in West Africa (Delon et al., 2012) to calculate NO release to the atmosphere. Concerning the GENDEC model, it has been successfully applied for situations very different from those upon which it was based (Moorhead and Reynolds, 1993; Moorhead at al., 1996). In other words, we can seriously consider using this coupled STEP-GENDEC-NOflux model in the Sahelian belt by making approximations, concerning for example biomass, livestock, $\mathrm{N}$ and $\mathrm{C}$ pools. Considering the need for information in this region of the world, it would be conceivable to simulate such processes of emissions at a larger scale. The challenge is worth taking on, knowing that NO emissions participate at a larger scale to the production of tropospheric ozone.

\section{Conclusions}

The present work is an attempt to estimate NO fluxes in the semi-arid region of the Sahel. Simulations are performed at the site of Agoufou (Mali), with a coupled vegetation-litter decomposition-NO emission model, for years 2004, 2005, 2006, 2007 and 2008. The vegetation model STEP correctly reproduces the temporal dynamics of soil moisture in the first layer of the model (layer involved in the soil $\mathrm{N}$ cycle), as well as the increase and decrease, and the filling and emptying of the surface layer. The temperature in the first two layers of the model are also in accordance with measurements. The green and dry biomass calculated by STEP show a correct feature when compared to measurements in terms of vegetation growth, vegetation quantity, decay and production of litter, despite slight time lags in the peak of green biomass for the years 2006 and 2008. The quantity of $\mathrm{N}$ is calculated in GENDEC, and is directly derived from organic matter and C contents, both quantities calculated from litter degradation and microbial dynamics in the soil. Sahelian soils are usually considered as $\mathrm{N}$ poor, and the comparison of the $\mathrm{N}$ content in the soil calculated in GENDEC (around 0.2-0.3\%) is well in accordance with experimental values, and with the few references found in the literature. The coupling between the three models is successful, and well adapted to the specific functioning of semi-arid ecosystems, where mechanistic models have usually not been tested. The biomass management in the Sahel is also driven by the presence of livestock, which provides faecal biomass and buries surface litter by trampling.

The quantity of $\mathrm{N}$ in the soil is the consequence of the presence of vegetation and livestock at the surface, and mineral $\mathrm{N}$ constitutes the $\mathrm{N}$ pool available for $\mathrm{N}$ release to the atmosphere, in the form of NO (and other compounds). The NO flux calculated by the model is of course highly dependent on soil moisture, as well as on mineral nitrogen, and a $2 \%$ fraction of this pool is used as input to calculate the NO release, modulated by the effect of environmental parameters such as wind speed, soil moisture and temperature, $\mathrm{pH}$ and sand percentage. Simulated NO emissions during the wet season are of the same order as previous measurements made at several sites where the vegetation and the soil are comparable to the ones in Agoufou. Measurements during the dry season are even scarcer in the literature than during the wet season, which complicates even more the validation of the modelling results. However, the annual budget of emissions is mostly 
dominated by emissions occurring during the wet season, as already highlighted in different studies in semi-arid regions.

This modelling study has been strengthened at each step of the calculation process by comparison with experimental values. It would be necessary to obtain more measurements through field campaigns, especially for the $\mathrm{N}$ content in the soil, the grazing pressure, the soil $\mathrm{N}$ uptake by plants, and the concentrations and fluxes of $\mathrm{N}$ compounds in the atmosphere. Taking into account the difficulty of organizing field campaigns in these remote regions, modelling is an essential tool to link $\mathrm{N}$ cycles both in the soil and in the atmosphere, and to understand specific processes involved in semi-arid regions. This study is a step forward in the representation of biogenic NO release to the atmosphere in semi-arid regions, where processes of emissions are usually adapted from temperate regions, and not specifically designed for semi-arid ecosystems.

Acknowledgements. The authors thank the reviewers and the editor S. Noe for their help in improving the paper. Special thanks to Corinne Jambert for her wise and useful advice on flux measurement techniques. D. Moorhead is also acknowledged for providing us with the GENDEC model.

Edited by: S. M. Noe

\section{References}

Adon, M., Galy-Lacaux, C., Yoboué, V., Delon, C., Lacaux, J. P., Castera, P., Gardrat, E., Pienaar, J., Al Ourabi, H., Laouali, D., Diop, B., Sigha-Nkamdjou, L., Akpo, A., Tathy, J. P., Lavenu, F., and Mougin, E.: Long term measurements of sulfur dioxide, nitrogen dioxide, ammonia, nitric acid and ozone in Africa using passive samplers, Atmos. Chem. Phys., 10, 7467-7487, doi:10.5194/acp-10-7467-2010, 2010.

Adon, M., Galy-Lacaux, C., Delon, C., Yoboue, V., Solmon, F., and Kaptue Tchuente, A. T.: Dry deposition of nitrogen compounds $\left(\mathrm{NO}_{2}, \mathrm{HNO}_{3}, \mathrm{NH}_{3}\right)$, sulfur dioxide and ozone in west and central African ecosystems using the inferential method, Atmos. Chem. Phys., 13, 11351-11374, doi:10.5194/acp-13-11351-2013, 2013.

Blagodatsky S., Grote, R., Kiese, R., Werner, C., and ButterbachBahl, K.: Modelling of microbial carbon and nitrogen turnover in soil with special emphasis on N-trace gases emission, Plant Soil, 346, 297-330, 2011.

Butterbach-Bahl, K., Kesik, M., Miehle, P., Papen, H., and Li, C.: Quantifying the regional source strength of $\mathrm{N}$-trace gases across agricultural and forest ecosystems with process based models, Plant Soil, 260, 311-329, 2004a

Butterbach-Bahl, K., Kock, M., Willibald, G., Hewett, B., Buhagiar, S., Papen H., and Kiese, R.: Temporal variations of fluxes of $\mathrm{NO}, \mathrm{NO}_{2}, \mathrm{~N}_{2} \mathrm{O}, \mathrm{CO}_{2}$ and $\mathrm{CH}_{4}$ in a tropical rain forest ecosystem, Global Biogeochem. Cy., 18, GB3012, doi:10.1029/2004GB002243, 2004b.

Butterbach-Bahl, K., Kahl M., Mykhayliv L., Werner C., Kiese R., and Li C.: A European-wide inventory of soil NO emissions using the biogeochemical model DNDC/Forest-DNDC, Atmos. Environ., 43, 1392-1402, 2009.

Cardenas, L., Rondon, A., Johansson, C., and Sanhueza, E.: Effects of soil moisture, temperature and inorganic nitrogen on nitric oxide emissions from acidic tropical savannah soils, J. Geophys. Res., 98, 14783-14790, 1994.

Conrad, R.: Soil microorganisms as controllers of atmospheric trace gases $\left(\mathrm{H}_{2}, \mathrm{CO}, \mathrm{CH}_{4}, \mathrm{OCS}, \mathrm{N}_{2} \mathrm{O}\right.$, and $\left.\mathrm{NO}\right)$, Microbiol. Rev., 60, 609-640, 1996.

Conrad, R.: Compensation concentration as critical variable for regulating the flux of trace gases between soil and atmosphere, Biogeochemistry, 27, 155-170, 1994.

Davidson, E. A.: Fluxes of nitrous oxide and nitric oxide from terrestrial ecosystems, in: Microbial Production and Consumption of Greenhouse Gases: Methane, Nitrogen Oxides and Halomethanes, edited by: Rogers, J. E. and Whitman, W. B., American Society for Microbiology, Washington, 219-235, 1991.

Davidson, E. A. and Kingerlee, W.: A global inventory of nitric oxide emissions from soils, Nutr. Cycl. Agroecosys., 48, 37-50, 1997.

Davidson E. A., Keller, M., Erickson, H. E., Verchot, L. V., and Veldkamp, E.: Testing a conceptual model of soil emissions of nitrous and nitric oxides, Biosciences, 50, 667-680, 2000.

De Bruin, B., Penning de Vries, F. W. T., Van Broekhoven, L. W., Vertrgt, N., and Van de Geijn, S. C.: Net mineralization, nitrification and $\mathrm{CO}_{2}$ production in alternating moisture conditions in an unfertilized low humus sandy soil from the Sahel, Plant Soil, 113, 69-78, 1989.

Delmas, R., Peuch, V.-H., Megie, G., and Brasseur, G. P.: Emissions anthropiques et naturelles et dépôts, in Physique et chimie de l'atmosphere, Eds Belin,, Chap. 5, ISBN: 2-7011-3700-4, 1995 (in French).

Delon, C., Serça, D., Boissard, C., Dupont, R., Dutot, A., Laville, de Rosnay, P., and Delmas, R.: Soil NO emissions modelling using artificial neural network, Tellus, 59B, 502-513, 2007.

Delon, C., Reeves, C. E., Stewart, D. J., Serça, D., Dupont, R., Mari, C., Chaboureau, J.-P., and Tulet, P.: Biogenic nitrogen oxide emissions from soils - impact on $\mathrm{NO}_{\mathrm{x}}$ and ozone over West Africa during AMMA (African Monsoon Multidisciplinary Experiment): modelling study, Atmos. Chem. Phys., 8, 2351-2363, doi:10.5194/acp-8-2351-2008, 2008.

Delon, C., Galy-Lacaux, C., Boone, A., Liousse, C., Serça, D., Adon, M., Diop, B., Akpo, A., Lavenu, F., Mougin, E., and Timouk, F.: Atmospheric nitrogen budget in Sahelian dry savannas, Atmos. Chem. Phys., 10, 2691-2708, doi:10.5194/acp-10-26912010, 2010.

Delon, C., Galy-Lacaux, C., Adon, M., Liousse, C., Serça, D., Diop, B., and Akpo, A.: Nitrogen compounds emission and deposition in West African ecosystems: comparison between wet and dry savanna, Biogeosciences, 9, 385-402, doi:10.5194/bg-9-385-2012, 2012.

De Rosnay, P., Gruhier, C., Timouk, F., Baup, F., Mougin, E., Hiernaux, P., Kergoat, L., and LeDantec, V: Multiscale soil moisture measurements at the Gourma meso-scale site in Mali, J. Hydrol., 375, 241-252, 2009.

Diallo, A. and Gjessing, J.: Natural resources management: Morpho-pedology in Gourma region, SSE Research program 
Mali-Norway, CNRST-IER-Oslo University (Norway), 1-19, 1999 (in French).

Feig, G. T., Mamtimin, B., and Meixner, F. X.: Soil biogenic emissions of nitric oxide from a semi-arid savanna in South Africa, Biogeosciences, 5, 1723-1738, doi:10.5194/bg-5-17232008, 2008.

Firestone, M. K. and Davidson, E. A.: Microbial basis of NO and $\mathrm{N}_{2} \mathrm{O}$ production and consumption in soil, in: Andreae MO, edited by: Schimel D. S., Exchange of Trace Gases between Terres trial Ecosystems and the Atmosphere, New York, John Wiley and Sons, 7-21, 1989.

Fowler, D., Pilegaard, K., Sutton, M. A., Ambus, P., Raivonen, M., Duyzer, J., Simpson, D., Fagerli, H., Fuzzi, S., Schjoerring, J. K., Granier, C., Neftel, A., Isaksenm, I. S. A., Laj, P., Maione, M., Monks, P. S., Burkhardt, J., Daemmgen, U., Neirynck, J., Personne, E., Wichink-Kruit, R., Butterbach-Bahl, K., Flechard, C., Tuovinen, J. P., Coyle, M., Gerosa, G., Loubet, B., Altimir, N., Gruenhage, L., Ammann, C., Cieslik, S., Paoletti, E., Mikkelsen, T. N., Ro-Poulsen, H., Cellier, P., Cape, J. N., Horva, L., Loreto, F., Niinemets, U., Palmer, P. I., Rinne, J., Misztal, P., Nemitz, E., Nilsson, D., Pryor, S., Gallagher, M. W., Vesala, T., Skiba, U., Brüggemann, N., Zechmeister-Boltenstern, S., Williams, J., O'Dowdap, C., Facchini, M. C., de Leeuw, G., Flossman, A., Chaumerliac, N., and Erisman, J. W.: Atmospheric composition change: Ecosystems-Atmosphere interactions, Atmos. Environ., 43, 5193-5267, 2009.

Frison, P. L., Mougin, E., and Hiernaux, P.: Observations and interpretation of ERS wind-scatterometer data over northern Sahel (Mali), Remote Sens. Environ., 63, 233-242, 1998.

Frison, P.-L., Mougin, E., Jarlan, L., Karam, M. A., and Hiernaux, P.: Comparison of ERS Wind-Scatterometer and SSM/IData for Sahelian Vegetation Monitoring, IEEE T. Geosci. Remote, 38, 1794-1803, 2000.

Galbally, I. E. and Johansson, C.: A model relating laboratory measurements of rates of nitric oxide production and field measurements of nitric oxide emission from soils, J. Geophys. Res., 94, 6473-6480, 1989.

Galy-Lacaux, C., Laouali, D., Descroix, L., Gobron, N., and Liousse, C.: Long term precipitation chemistry and wet deposition in a remote dry savanna site in Africa (Niger), Atmos. Chem. Phys., 9, 1579-1595, doi:10.5194/acp-9-1579-2009, 2009.

Hartley, A. E. and Schlesinger, W. H.: Environmental controls on nitric oxide emission from northern Chihuahuan desert soils, Biogeochemistry, 50, 279-300, 2000.

Hiernaux, P. and Le Houérou, H. N.: Les parcours du Sahel, Sècheresse, 17, 51-71, 2006.

Hiernaux H., Mougin, E., Diarra, L., Soumaguel, N., Lavenu, F., Tracol, Y., and Diawara, M.: Sahelian rangeland response to changes in rainfall over two decades in the Gourma region, Mali, J. Hydrol., 375, 114-127, 2009.

Hudman, R. C., Russell, A. R., Valin, L. C., and Cohen, R. C.: Interannual variability in soil nitric oxide emissions over the United States as viewed from space, Atmos. Chem. Phys., 10, $9943-$ 9952, doi:10.5194/acp-10-9943-2010, 2010.

Hudman, R. C., Moore, N. E., Mebust, A. K., Martin, R. V., Russell, A. R., Valin, L. C., and Cohen, R. C.: Steps towards a mechanistic model of global soil nitric oxide emissions: implementation and space based-constraints, Atmos. Chem. Phys., 12, 7779-7795, doi:10.5194/acp-12-7779-2012, 2012.
Jaeglé, L., Martin, R. V., Chance, K., Steinberger, L., Kurosu, T. P., Jacob, D. J., Modi, A. I., Yoboué, V., Sigha-Nkamdjou, L., and Galy-Lacaux, C.: Satellite mapping of rain-induced nitric oxide emissions from soils, J. Geophys. Res., 109, D21310, doi:10.1029/2003JD004406, 2004.

Jambert C., Serça, D., and Delmas, R.: Quantification of N-losses as $\mathrm{NH}_{3}, \mathrm{NO}$, and $\mathrm{N}_{2} \mathrm{O}$ and $\mathrm{N}_{2}$ from fertilized maize fields in southwestern France, Nutr. Cycl. Agroecosys., 48, 91-104, 1997.

Jarlan, L., Mougin, E., Frison, P. L., Mazzega, P., and Hiernaux, P.: Analysis of ERS wind scatterometer time series over Sahel (Mali), Remote Sens. Environ., 81, 404-415, 2002.

Jarlan, L., Mazzega, P., Mougin, E., Lavenu, F., Marty, G., Frison, P. L., and Hiernaux, P.: Mapping of Sahelian vegetation parameters from ERS scatterometer data with an evolution strategies algorithm, Remote Sens. Environ., 87, 72-84, 2003.

Jarlan, L., Mangiarotti, S., Mougin, E., Mazzega, P., Hiernaux, P., and Le Dantec, V.: Assimilation of SPOT/VEGETATION NDVI data into a sahelian vegetation dynamics model, Remote Sens. Environ., 112, 1381-1394, 2008.

Kesik, M., Ambus, P., Baritz, R., Brüggemann, N., ButterbachBahl, K., Damm, M., Duyzer, J., Horváth, L., Kiese, R., Kitzler, B., Leip, A., Li, C., Pihlatie, M., Pilegaard, K., Seufert, S., Simpson, D., Skiba, U., Smiatek, G., Vesala, T., and ZechmeisterBoltenstern, S.: Inventories of $\mathrm{N} 2 \mathrm{O}$ and $\mathrm{NO}$ emissions from European forest soils, Biogeosciences, 2, 353-375, doi:10.5194/bg2-353-2005, 2005.

Kim, D.-G., Vargas, R., Bond-Lamberty, B., and Turetsky, M. R.: Effects of soil rewetting and thawing on soil gas fluxes: a review of current literature and suggestions for future research, Biogeosciences, 9, 2459-2483, doi:10.5194/bg-9-2459-2012, 2012.

Krul, J. M., Penning de Vries, F. W. T., and Traore, K.: Les processus du bilan d'azote, in: La productivite des paturages saheliens, edited by: Penning de Vries, P. W. T. and Djiteye, M. A., Agr. Res. Rep. 916., Pudoc, Wageningen, The Netherlands, 226-246, 1982.

Laouali D., Galy-Lacaux, C., Diop, B., Delon, C., Orange, D., Lacaux, J. P., Akpo, A., Lavenu, F., Gardrat, E., and Castera, P. Long term monitoring of the chemical composition of precipitation and wet deposition fluxes over three Sahelian savannas, Atmos. Enivorn., 50, 314-327, 2012.

Laville P., Lehuger, S., Loubet, B., Chaumartin, F., and Cellier, P.: Effect of management, climate and soil conditions on $\mathrm{N}_{2} \mathrm{O}$ and $\mathrm{NO}$ emissions from an arable crop rotation using high temporal resolution measurements, Agric. Forest Meteorol., 151, 228240, 2011.

Le Roux, X., Abbadie, L., Lensi, R., and Serça, D.: Emission of nitrogen monoxide from African tropical ecosystems: Control of emission by soil characteristics in humid and dry savannas of West Africa, J. Geophys. Res., 100, 23133-23142, 1995.

Lo Seen, D., Mougin, E., Rambal, S., Gaston, A., and Hiernaux, P.: A regional sahelian grassland model to be coupled with multispectral satellite data. II. Towards the control of its simulations by remotely sensed indices, Remote Sens. Environ., 52, 194-206, 1995.

Li C., Aber, J., Stange, F., Butterbach-Bahl, K., and Papen, H.: A process-oriented model of $\mathrm{N}_{2} \mathrm{O}$ and $\mathrm{NO}$ emissions from forest soils: 1. Model development, J. Goephys. Res., 105, 4369-4384, 2000. 
Ludwig, J., Meixner, F. X., and Vogel, B.: Forstner J, Soil-air exchange of nitric oxide: An overview of processes, environmental factors, and modelling studies, Biogeochemistry, 52, 225-257, 2001.

Martin, R. E., Scholes, M. C., Mosier, A. R., Ojima, D. S., Holland, E. A., and Parton, W. J.: Controls on annual emissions of nitric oxide from soils of the Colorado shortgrass steppe, Global Biogeochem. Cy., 12, 81-91, 1998.

McCalley, C. K. and Sparks, J. P.: Controls over nitric oxide and ammonia emissions from Mojave Desert soils, Oecologia, 156, 871-881, 2008.

Medinets S., Skiba, U.,. Rennenberg, H., and Butterbach-Bahl, K.: A review of soil NO transformation: Associated processes and possible physiological significance on organisms, Soil Biol. Biochem., 80, 92-117, 2015.

Meixner F. X., Fickinger, T., Marufu, L., Serça, D., Nathaus, F. J., Makina, E., Mukurumbira, L., and Andreae, M. O.: Preliminary results on nitric oxide emission from a southern African savanna ecosystem, Nutr. Cycling Agroecosyst., 48, 123-138, 1997.

Meixner, F. X. and Yang, W. X.: Biogenic emissions of nitric oxide and nitrous oxide from arid and semi-arid land, Dryland Ecohydrology, edited by: DÓdoroco, P. and Porporato, A., by Kluwer Academic Publishers B.V., Dordrecht, The Netherlands, 233255, 2006

Moorhead, D. L. and Reynolds, J. F.: A general model of litter decomposition in the northern Chihuahuan desert, Ecol. Modell., 56, 197-219, 1991.

Moorhead, D. L. and Reynolds, J. F.: Effects of climate change on decomposition in arctic tussock tundra: a modelling synthesis, Arct. Alpine Res., 25, 403-412, 1993.

Moorhead, D. L., Sinsabaughb, R. L., Linkins, A. E., and Reynolds, J. F.: Decomposition processes: modelling approaches and applications, Sci. Total Environ., 183, 137-149, 1996.

Mougin, E., Lo Seen, D., Rambal, S., Gaston, A., and Hiernaux, P.: A Regional Sahelian Grassland Model To Be Coupled with Multispectral Satellite Data. I: Model Description and Validation, Remote Sens. Environ., 52, 181-193, 1995.

Mougin, E., Hiernaux, P., Kergoat, L., Grippa, M., De Rosnay, P., Timouk, F., Le Dantec, V., Demarez, V., Arjounin, M., Lavenu, F., Soumaguel, N., Ceschia, E., Mougenot, B., Baup, F., Frappart, F., Frison, P. L., Gardelle, J., Gruhier, C., Jarlan, L., Mangiarotti, S., Sanou, B., Tracol, Y., Guichard, F., Trichon, V., Diarra, L., Soumaré, A., Koité, M., Dembélé, F., Lloyd, C., Hanan, N. P., Damesin, C., Delon, C., Serça, D., Galy-Lacaux, C., Seghiéri, J., Becerra, S., Dia, H., Gangneron, F., and Mazzega, P.: The AMMA-CATCH Gourma observatory site in Mali: Relating climatic variations to changes in vegetation, surface hydrology, fluxes and natural resources, J. Hydrol., AMMA-CATCH Special issue, 375, 14-33, 2009.

Mougin, E., Demarez, V., Hiernaux, P., Diawara, M., and Berg, A.: Estimation of LAI, fCover and fAPAR of Sahel rangelands (Gourma, Mali), Agric. Forest Meteorol., 198-199, 155-167, 2014.

Otter, L. B., Yang, W. X., Scholes, M. C., and Meixner, F. X.: Nitric oxode emissions from a southern african savanna, J. Geophys. Res, 104, 18471-18485, 1999.

Pape, L., Ammann, C., Nyfeler-Brunner, A., Spirig, C., Hens, K., and Meixner, F. X.: An automated dynamic chamber system for surface exchange measurement of non-reactive and reactive trace gases of grassland ecosystems, Biogeosciences, 6, 405429, doi:10.5194/bg-6-405-2009, 2009.

Parton, W. J.: Predicting soil temperatures in a shortgrass steppe, Soil Sci., 138, 93-101, 1984.

Parton, W. J., Holland, E. A., Del Grosso, S. J., Hartman, M. D., Martin, R. E., Mosier, A. R., Ojima, D. S., and Schimel, D. S.: Generalized model for NOx and $\mathrm{N}_{2} \mathrm{O}$ emissions from soils, J. Geophys. Res., 106, 17403-17419, 2001.

Pierre, C., Bergametti, G., Marticorena, B., Mougin, E., and Bouet, C.: Schmechtig C, Impact of vegetation and soil moisture seasonal dynamics on dust emissions over the Sahelian belt in West Africa, J. Geophys. Res., 117, D06115, doi:10.1029/2011JD016950, 2012.

Pierre, C., Bergametti, G., Marticorena, B., Mougin, E., Lebel, T., and Ali, A.: Pluriannual comparisons of satellite-based rainfall products over the Sahelian belt for seasonal vegetation modeling, J. Geophys. Res., 116, D18201, doi:10.1029/2011JD016115, 2011.

Pihlatiea, M. K., Christiansen, J. R., Aaltonen, H., Korhonen, J. F. J., Nordbo, A., Rasilo, T., Benanti, G., Giebels, M., Helmy, M., Sheehy, J., Jones, S., Juszczak, R., Klefoth, R., Lobo-do-Vale, R., Rosa, A. P., Schreiber, P., Serça, D., Vicca, S., Wolf, B., and Pumpanen, J.: Comparison of static chambers to measure $\mathrm{CH}_{4}$ emissions from soils, Agr. Forest Meteorol., 171-172, 124-136, 2013.

Pilegaard, K.: Processes regulating nitric oxide emissions from soils, Phil. Trans. R. Soc. B, 368, 20130126, 2013.

Potter, C. S., Matson, P. A., Vitousek, P. M., and Davidson, E. A.: Process modelin of controls on nitrogen trace gas emissions from soils worldwide, J. Geophys. Res., 101, 1361-1377, 1996.

Redelsperger J.-L., Thorncroft, C. D., Diedhiou, A., Lebel, T., Parker, D. J., and Polcher, J.: African Monsoon Multidisciplinary Analysis: An International Research Project and Field Campaign, Bull. Amer. Meteor. Soc., 87, 1739-1746, 2006.

Schindlbacher, A., Zechmeister-Boltenstern, S., and ButterbachBahl, K.: Effects of soil moisture and temperature on $\mathrm{NO}, \mathrm{NO}_{2}$ and $\mathrm{N}_{2} \mathrm{O}$ emissions from European forest soils, J. Geophys. Res., 109, D17302, doi:10.1029/2004JD004590, 2004.

Scholes, M. C., Martin, R., Scholes, R. J., Parsons, D., and Winstead, E.: $\mathrm{NO}$ and $\mathrm{N}_{2} \mathrm{O}$ emissions from savanna soils following the first simulated rains of the season, Nutr. Cycl. Agroecosys. 48- 115-122, 1997.

Schreiber, F., Wunderlin, P., Udert K. M., and Wells, G. F.: Nitric oxide and nitrous oxide turnover in natural and engineered microbial communities: biological pathways, chemical reactions, and novel technologies, Front. Microbiol., 3, 372, doi:10.3389/fmicb.2012.00372, 2012.

Schwinning S., Sala, O. E., Loik, M. E., and Ehleringer, J. R. Thresholds, memory, and seasonality: understanding pulse dynamics in arid.semi-arid ecosystems, Oecologia, 141, 191-193, 2004.

Serça, D., Delmas, R., Jambert C., and Labroue, L.: Emissions of nitrogen oxides from equatorial rain forest in central Africa: Origin and regulation of NO emission from soils, Tellus, 46, 143-254, 1994.

Serça D., Delmas, R., Le Roux, X., Parsons, D. A. B., Scholes, M. C., Abbadie, L., Lensi, R., Ronce, O., and Labroue, L.: Comparison of nitrogen monoxide emissions from several African 
tropical ecosystems and influence of season and fire, Global Biogeochem. Cy., 12, 4, 637-651, 1998.

Skopp, J., Jawson, M. D., and Doran, J. W.: Steady state aerobic microbial activity as a function of soil water content, Soil Sci. Soc. Am. J., 54, 1619-1625, 1990.

Steinkamp, J. and Lawrence, M. G.: Improvement and evaluation of simulated global biogenic soil NO emissions in an AC-GCM, Atmos. Chem. Phys., 11, 6063-6082, doi:10.5194/acp-11-60632011, 2011.

Sullivan, L. J.: Environmental variables controlling nitric oxide emissions from agricultural soils in the southeast united states, Atmospheric Environ., 30, 3573-3582, 1996.

Tracol, Y., Mougin, E., Hiernaux, P., and Jarlan, L.: Testing a sahelian grassland functioning model against herbage mass measurements, Ecol. Modell. 193, 437-446, 2006.

van Dijk, S. M., Gut, A., Kirkman, G. A., Meixner, F. X., Andreae, M. O., and Gomes, B. M.: Biogenic NO emissions from forest and pasture soils: Relating laboratory studies to field measurements, J. Geophys. Res., 107, D20, LBA 25-1-LBA 25-11, doi:10.1029/2001JD000358, 2002.

Van Dijk, S. and Meixner, F. X.: Production and consumption of NO in forest and pasture soils from the Amazon Basin: a laboratory study, Water, Air and Soil Pollution: Focus, 1, 119-130, 2001.
Vitousek, P. M., Menge, D. N. L., Reed, S. C., and Cleveland, C. C.: Biological nitrogen fixation: rates, patterns and ecological controls in terrestrial ecosystems, Phil. Trans. R. Soc. B, 368, 20130119, doi:10.1098/rstb.2013.0119. 2013

Williams, E. J., Guenther, A., and Fehsenfeld, F. C.: An inventory of nitric oxide emissions from soils in the United States, J. Geophys. Res. 97, 7511-7519, 1992.

Yan, X., Ohara, T., and Akimoto, H.: Statistical modelling of global soil NOx emissions, Global Biogeochem. Cy., 19, GB3019, doi:10.1029/2004GB002276, 2005.

Yang, W. X. and Meixner, F. X.: Laboratory studies on the release of nitric oxide from sub-tropical grassland soils: The effect of soil temperature and moisture, in: Gaseous Nitrogen Emissions from Grasslands, edited by: Jarvis, S. C. and Pain, B. F., CAB International, Wallingford, New York, 67-70, 1997.

Yao, Z, Wu, X., Wolf, B., Dannenmann, M., Butterbach-Bahl, K., Brüggemann, N., Chen, W., and Zheng, X.: Soil atmosphere exchange potential of $\mathrm{NO}$ and $\mathrm{N}_{2} \mathrm{O}$ in different land use types of Inner Mongolia as affected by soil temperature, soil moisture, freeze-thaw, and drying- wetting events, J. Geophys. Res., 115, D17116, doi:10.1029/2009JD013528, 2010.

Yienger, J. J. and Levy II, H.: Empirical model of global soil biogenic NOx emissions, J. Geophys. Res., 100, 11447-11464, 1995. 